\title{
UV-Induced Immune Suppression that Promotes Skin Cancer Development and Progression
}

\author{
Takuma Kato and Linan Wang \\ Department of Cellular and Molecular Immunology \\ Department of Immuno-Gene Therapy \\ Mie University Graduate School of Medicine \\ Japan
}

\section{Introduction}

Arguably, UV irradiation is one of the most relevant risk factors for the development of skin cancer, including basal and squamous cell carcinoma (SCC), and melanoma (Rigel, 2008). UV-induced DNA damage triggers specific genetic mutations in oncosuppressor genes and/or oncogenes that initiate downstream events for carcinogenesis (de Gruijl \& Rebel, 2008). It is increasingly clear that immunity plays a protective role in the detection and elimination of nascent tumors. This process termed "cancer immunosurveillance" has undergone a renaissance with the aid of elegant studies of cancer development in genetically engineered (targeting and/or transgenic) animals, and turned into the refined hypothesis termed "cancer immunoediting" (Vesely et al., 2011). UV radiation suppresses a variety of immune responses that contribute to carcinogenesis. The immunosuppressive effects of UV radiation may be involved in skin cancer development by impairing the antitumor immune responses that can destroy developing skin tumors. Moreover, UV radiation induces antigen-specific immune tolerance, which is largely mediated by regulatory $\mathrm{T}$ cells that specifically suppress immune responses against antigens expressed on emerging tumors (Katiyar, 2007). The temporal relationship between UV radiation and carcinogenesis revealed that UV radiation initiates tumor formation followed by suppression of immune responses specific to emerging tumors. Thus, the experiments documenting the immune suppressive effects of UV were conducted using naïve animals exposed to UV radiation prior to immunization. Accordingly, the prevailing notion of UVinduced immune suppression places a supportive role of UV radiation for the initiation of tumor development. However, it is equally important to explore the possibility that UV radiation induces antigen-specific immune suppression in hosts that have established immunity toward corresponding antigen, since UV radiation may suppress anti-tumor immune responses against emerging skin tumors wherein UV radiation may play no causative roles but contributes to tumor progression. This notion of UV-induced immunosuppression contributing to the progression of already emerged tumors, has received less attention and is not well corroborated experimentally. It is important to note that some melanomas arise at sites such as palms, soles, and buttocks, which do not have obvious exposure to UV radiation. There is increasing concern for the decreasing stratospheric ozone levels that leads increase in exposure to short wave length UV-B 
radiation on the terrestrial surface (Urbach, 1991). Therefore, it is incumbent upon us to gain a better understanding of the mechanisms of UV-induced immunosuppression involved in not only cancers wherein UV radiation plays a carcinogenic role but also those wherein it does not play an obvious causative role.

Based on wavelength, UV light can be divided into three bands: UV-A $(\lambda=320-400 \mathrm{~nm})$, UV-B $(\lambda=280-320 \mathrm{~nm})$ and UV-C $(\lambda=200-280 \mathrm{~nm})$ (Tyrrell, 1994). The stratospheric ozone layer absorbs UV-C and most of UV-B, resulting in the UV component of sunlight reaching terrestrial biosphere consists primarily of UV-A (95\%) and UV-B (5\%) (Diffey, 2002). The energy carried by each UV component is inversely related to its wavelength and thus UV-B has been historically deemed to be the major UV component in sunlight affecting human health. However, UV-A is the most abundant UV component in sunlight and penetrates deep into the skin, thus quantitatively equally effective in affecting human health. Therefore carcinogenic and immunosuppressive properties of UV-A and UV-B can be dealt without distiction.

This chapter, in addition to presenting a comprehensive review of recent advances in the understanding of the causative roles of UV radiation in skin cancer development in the context of tumor immunology and the underlying cellular and molecular mechanisms involved, will also emphasize the notions of UV-induced immunosuppression contributing to the progression of already emerged tumors.

\section{UV-induced DNA damage results in the mutation of critical genes and the dysregulation of microRNA expression leading to malignant transformation}

Genome integrity in all living organisms is constantly threatened by endogenous and exogenous agents that modify the chemical integrity of DNA, collectively termed DNA damage, and in turn degenerate its informational contents (Wogan et al., 2004). If DNA damage is left unrepaired it can cause transcriptional silencing, proliferative arrest, and induce apoptosis (Hoeijmakers, 2001; Jackson \& Bartek, 2009). To combat threats posed by DNA damage, cells are equipped with numerous mechanisms to detect and repair DNA lesions (Harper \& Elledge, 2007; Harrison \& Haber, 2006; Wood et al., 2005). Notwithstanding, some lesions remain in DNA during replication and are replicated in an error-prone manner resulting in mutations that enhance cancer risk (Jacinto \& Esteller, 2007; Livneh, 2006). The most pervasive environmental DNA-damaging agent is UV radiation, and this is the primary basis for the carcinogenic properties of UV radiation. The International Agency for Research on Cancer published a monograph providing evidence for the carcinogenic properties of UV radiation in sunlight in 1992 (IARC, 1992) and now classifies UV radiation as a human carcinogen (http://monographs.iarc.fr/ENG/Classification/index.php). UV-induced DNA damage initiates a chain of events leading to carcinogenesis, collectively termed as "photocarcinogenesis". This process involves the formation of mutations at sites of DNA damage and, ultimately, results in malignant transformation after the accumulation of a sufficient number of mutations in critical genes (Runger, 2007). These mutations can occur in tumor suppressor genes such as p53 (Brash et al., 1991; Hussein et al., 2003; Rees, 1994; Ziegler et al., 1994; Ziegler et al., 1993), CDKN2/p16 (Holly et al., 1995; Saridaki et al., 2003; Soufir et al., 1999; Sparrow et al., 1998), and PTCH (D'Errico et al., 2000; Daya-Grosjean \& Sarasin, 2000; de Gruijl et al., 2001; Ping et al., 2001; Zhang et al., 2001) as well as proto-oncogenes such as RAS (Chan et al., 2002; Kreimer-Erlacher et al., 2001; Spencer et al., 1995; van der Schroeff et al., 1990) and RAF (Besaratinia \& Pfeifer, 2008; Gaddameedhi et al., 2010). UV-induced DNA damage also induces transcriptional activation of proto-oncogene c-fos (Ghosh et al., 1993). 


\subsection{DNA damage}

The heterocyclic bases of DNA efficiently absorb energy in the UV that results in DNA lesions through a photochemical reaction (Ely \& Ross, 1949). Thus the efficiency and the type of DNA lesion formation depends on the wavelength, peaking between $260 \mathrm{~nm}$ and 265 $\mathrm{nm}$ within the UV-B region (Markovitsi et al., 2010). The predominant form of DNA lesions are cyclobutane pyrimidine dimers (CPDs) and pyrimidine 6-4 pyrimidone photoproducts (6-4PPs), which constitute $65 \%$ and $35 \%$ of UV-B-induced DNA lesions, respectively (Lippke et al., 1981; Mitchell et al., 1992). Although direct absorption of photon energy by DNA is extremely low at the UV-A region, recent studies show that UV-A also triggers DNAdamage via formation of CPDs (Mouret et al., 2006; Rochette et al., 2003). Furthermore, UVA induces conversion of 6-4PPs into an isomeric secondary product, Dewar valence isomer (Douki et al., 2003; Perdiz et al., 2000). It has been estimated that strong sunlight can induce approximately 100,000 lesions per cell exposed per hour (Jackson \& Bartek, 2009). CPDs, 6$4 \mathrm{PPs}$ and Dewar valence isomers are induced by natural sunlight in normal human mononuclear cells (Clingen et al., 1995), and result in UV-specific mutations. These photolesions are highly mutagenic because of error-prone repair that results in thymidine substitutions. Although the contribution of 6-4PPs to UV-induced carcinogenesis has been elusive (Jans et al., 2006), the causative role of CPDs in UV-induced carcinogenesis was substantiated by specific removal of these DNA lesions through DNA repair enzymes leading to significantly reduced risk of UV-induced skin cancer in mice (Jans et al., 2005) and human (Yarosh et al., 1992; Yarosh et al., 2001). Besides the formation of DNA-lesions, cis-urocanic acid (cis-UCA) is formed from its isomer trans-UCA, which is abundant in skin exposed to UV radiation. A recent study showed direct evidence that cis-UCA induces reactive oxygen species (ROS) (Sreevidya et al., 2010) that leads the oxidative base modifications, predominantly at guanine base, and to the generation of the mutagenic DNA lesion, 8-oxo-7,8-dihydor-2' -deoxyguanosine (8-oxo-dG) (Douki et al., 1999; Kielbassa et al., 1997; Zhang et al., 1997). All these lesions are assumed to contribute to the generation of p53 mutations in SCC (Brash et al., 1991; Ziegler et al., 1994), Ras mutations in melanoma (Jiveskog et al., 1998), and p16 in actinic keratosis (Kanellou et al., 2008).

\section{2 microRNAs}

Recent studies implicate a small non-coding RNA species, microRNA, as a new player in the field of UV-induced carcinogenesis. microRNAs have important regulatory roles in diverse cellular pathways through their association with 3 '-untranslated region of target mRNAs (Bartel, 2004). Increasing evidence indicates that DNA damage induced by UV irradiation provokes profound changes in expression of microRNAs (Pothof et al., 2009). Enlightening findings on the microRNA expression profile have been obtained in mouse fibroblast cell line NIH3T3 irradiated with UV-B. UV-B irradiation resulted in robust changes in the microRNA expression profile including the upregulation of let-7a, miR-21, and miR-24 and the downregulation of miR-465 (Guo et al., 2009). Subsequent work on microRNA expression in primary human keratinocytes exposed to UV-A or UV-B radiation revealed that UV-A induces miR-21, miR-203, and miR-205, whereas UV-B moderately induces miR-203, reduces miR-205 and had no effect on miR-21 (Dziunycz et al., 2010). Of particular interest is the observation that UV-A, but not UV-B, increased the expression of miR-21, since UV-A is responsible for SCC formation to a much higher extent than UV-B (Dziunycz et al., 2010). miR-21 is one of the most studied microRNAs and has potent carcinogenic properties (Selcuklu et al., 2009). It is currently well recognized that UVR induces aberrant 
microRNA expression in response to DNA damage. As aberrant microRNA expression has been observed in a variety of cancers (Catto et al., 2011; Selcuklu et al., 2009), the carcinogenic property of UV through DNA-lesion formation may also involve microRNA misexpression. Therefore, UV-induced DNA-lesion that directly causes mutations in critical oncogenes, tumor suppressor genes, or transcriptional regulatory regions of these genes, and UV-mediated modification of microRNA expression may collaboratively induce malignant transformation.

Arguably, cells are equipped with a variety of intrinsic tumor-suppressor mechanisms that attempt to repair genetic mutations and trigger senescence or apoptosis in order to prevent transformation. Normal cells can be transformed into tumor cells by the combination of genetic mutation and failed intrinsic tumor-suppressor mechanisms. However, emerging transformed cells and precancerous cells are usually kept in check by the host immune system, which acts as an extrinsic tumor suppressor mechanism that senses the presence of cancerous cells and restricts their growth. In the following section, the concept of tumor immunosurveillance and its updated hypothesis of tumor immunoediting, as well as the mechanisms by which UV irradiation interferes with these processes to promote tumorigenesis will be explored.

\section{UV radiation suppresses the host immune system ability to eliminate emerging transformed cells}

\subsection{Cancer immunoediting}

The relative contribution of the immune system to the control of cancer development and growth has been debated for many years. It was not until 2010 that Hanahan and Weinberg reviewed "immunity" as an emerging hallmark of cancer (Hanahan \& Weinberg, 2011) expanded beyond their previous landmark review (Hanahan \& Weinberg, 2000), from which immunity was notably absent. Now, there is ample evidence supporting a protective role for immunity in the detection and elimination of nascent tumors. This process called "cancer immunosurveillance", originally conceived in 1909 by Paul Ehrlich and later hypothesized by Burnet and Thomas in the late 1950s, has undergone a renaissance with elegant studies of cancer development in genetically engineered (targeting and/or transgenic) animals, which have helped spawn the notion of "cancer immunoediting". Cancer immunoediting proposes that cancer development and growth are controlled by three sequential phases: elimination, equilibrium, and escape. The elimination phase of cancer immunoediting is equivalent to the process described in the original hypothesis of immunosurveillance, whereby innate and adaptive immunity collaborate to detect and eliminate tumor cells that have developed as a result of failed intrinsic tumor suppressor mechanisms mentioned previously. In instances in which tumor cell destruction goes to completion, the elimination phase represents an endpoint of cancer immunoediting. However, rare tumor cell variants may survive in the elimination phase, leading to an equilibrium state between host immune system and developing tumors. In this equilibrium phase, the host immune system controls net tumor cell outgrowth, which results in the tumor cells remaining functionally dormant, but also sculpts the immunogenicity of the tumor cells. During this phase, T cell-mediated adaptive immunity exerts potent and relentless selection pressure on the tumor cells that is enough to contain but not fully extinguish the tumor bed containing many genetically unstable and mutating tumor cells, which can be viewed as a crucible of Darwinian selection. This phase can last for the life of 
the host, in which case the host does not develop any clinical manifestations and the equilibrium phase represents the second stable endpoint of cancer immunoediting. However, the constant immune selection pressure placed on genetically unstable tumor cells may lead to the emergence of tumor cell variants with any of the following characteristics: (i) invisible to adaptive immunity (variants with antigen loss or defect in antigen processing or presentation), (ii) insensitive to immune effector mechanisms, and (iii) ability to induce an immunosuppressive state within the tumor microenvironment, collectively referred lowimmunogenic tumor variants. Therefore, although many of the original tumor cells that have survived in the elimination phase are destroyed, new variants arise that carry different mutations and altered gene expression profiles which endow them with the means to subvert immune-mediated recognition and destruction. Moreover, the growth of the selected variants is no longer controlled by immune system, leading to the appearance of overt cancer in the escape phase. In the escape phase, tumor cells that have acquired the ability to circumvent immune recognition or destruction emerge as progressively growing tumors and induce various clinical manifestations.

Evidence in support of the process of immunoediting comes mainly from mouse studies comparing the properties of tumors induced by chemical carcinogens in animals that are either immunocompetent or immunodeficient; however, increasing clinical observations have also provided evidence supporting the notion of tumor immunoediting in humans. In mice, immunodeficient mice develop more tumors, more rapidly, and at lower chemical carcinogen doses than wild-type immunocompetent mice (Dighe et al., 1994; Kaplan et al., 1998; Shankaran et al., 2001; Smyth et al., 2001; Street et al., 2001; Street et al., 2002). Immunodeficient mice also display an increased incidence of disseminated lymphomas or spontaneous lung adenocarcinomas, depending on mouse strains. Furthermore, tumors cell lines derived from immunocompetent mice survive well in both immunocompetent and immunodeficient mice upon transplantation, whereas those derived from immunodeficient mice survive only in immunodeficient mice and are easily rejected in immunocompetent mice, indicating that tumors developed in immunocompetent mice are edited to be less immunogenic. In humans, patients with AIDS and organ transplantation recipients that have received immunosuppressants have increased frequencies of malignancies. Although virus-associated malignancies predominate and thus an argument can be made that the increased frequency of virus-associated cancers reflects a breakdown in antiviral immunity rather than reduced immunosurveillance of cancer, these is also an increased risks for the development of noninfectious cancers (Boshoff \& Weiss, 2002; Chaturvedi et al., 2007; Frisch et al., 2001; Vajdic et al., 2006). In relation to skin cancer, a 200-fold increased risk of nonmelanoma skin cancers and 2- to 10-fold increased frequency of melanomas have been reported in renal transplant patients (Moloney et al., 2006). Patients with liver transplants also manifest a greater preponderance of nonmelanoma skin cancers (Aberg et al., 2008). Furthermore, there is a direct correlation between the duration of immunosuppressant administration and the incidence of cancer development (Loeffelbein et al., 2009), supporting the existence of human cancer immunosurveillance.

Most of the observations that the immunosuppressive status of the host may promote tumor development and growth largely recapitulate the studies conducted in UV-irradiated mice, in which the pioneering work of Fisher and Kripke established the field of photoimmunology, involving elements of photobiology, immunology, and oncology (Fisher \& Kripke, 1977). In the following sections, we will deal with UV-induced immune suppression that supports tumor development and progression. 


\subsection{UV radiation suppresses anti-tumor immunity and promotes tumor development}

The first clear evidence that UV irradiation can affect immune responses emanated from the seminal work of Margaret Kripke and her colleagues in the 1970's, who demonstrated that skin tumors induced by chronic exposure to UV radiation were highly immunogenic, as they were rejected when transplanted into age- and sex-matched healthy syngeneic mice. In hindsight, the tumors developed in UV-irradiated hosts were not edited. They further showed that prior exposure of recipient mice to subcarcinogenic doses of UV-B resulted in the acceptance of the transplanted tumors, clearly indicating that UV systemically suppresses host immunity against tumors (DeFabo \& Kripke, 1979; Fisher \& Kripke, 1977; Kripke, 1974). Tumors were accepted even when transplanted into sites not directly exposed to UV radiation, indicating that UV radiation exerts systemic immunosuppression (DeFabo \& Kripke, 1979; Fisher \& Kripke, 1977). The effect of UV on the acceptance of the transplanted tumors was shown to be UV dose-dependent. In another study in primary tumor development model using UV independently as an immunosuppressant and a tumor initiator, de Gruijl et al. demonstrated the immunosuppressive effect of UV via the inhibition of cancer immunosurveillance leading to the acceleration of tumorigenesis (de Gruiji \& van der Leun, 1982; de Gruijl \& Van Der Leun, 1983). In these studies, hairless mice were pre-irradiated with UV radiation while certain skin areas of the animals were shielded from the radiation. Pre-irradiation was carried out to the point where tumors started to appear in the pre-irradiation skin areas (13 weeks). Then, the initially shielded skin areas were chronically exposed to UV radiation, which resulted in the development of tumors in these skin areas. They demonstrated that the formation of tumors in the initially shielded skin areas was enhanced by the pre-irradiation of the other skin areas. Subsequently, they also showed that the formation of tumors in initially shielded skin areas was still enhanced even when the pre-irradiation was discontinued long before the appearance of tumor in preirradiated skin areas. These earlier studies revealed that UV irradiation disturbs cancer immunosurveillance, leading to the accelerated development of tumors and the emergence of highly immunogenic (non-edited) tumors. Collectively, these results indicate that UV-B radiation has a dual effect on skin carcinogenesis, not only as an inducer, but also as a promoter. Subsequent studies utilizing models of contact hypersensitivity (CHS), wherein mice were sensitized by epicutaneous application of contact allergens induced an ear swelling response, recapitulated the immunosuppressive features of UV radiation seen in skin carcinogenesis (Noonan et al., 1981; Toews et al., 1980). In these studies, mice sensitized with a hapten to the skin that had been exposed to UV-defected CHS responses (Toews et al., 1980). Furthermore, these mice exhibited systemic and long-term unresponsiveness to the same hapten, since the mice could not be re-sensitized against the same hapten at a later time point even when the hapten was applied to skin not previously exposed to UV. This unresponsiveness was antigen-specific, since the mice exhibited normal CHS responses against other unrelated haptens. These studies unravel important features of UV-induced immunosuppression, particularly long-lasting and antigen specific immune responses.

\subsection{Regulatory T cells are responsible for the UV-induced suppression of anti-tumor immunity}

Early work on UV-induced immunosuppression by Kripke and colleagues revealed that UV-B induced immunosuppression was transferable by adoptive transfer of lymphocytes from irradiated mice into non-irradiated mice (Fisher \& Kripke, 1977; Hostetler et al., 1989; Kripke \& Fisher, 1976; Kripke et al., 1977; Kripke et al., 1979; Roberts et al., 1982; Spellman \& 
Daynes, 1977; Spellman \& Daynes, 1984; Spellman et al., 1977; Ullrich \& Kripke, 1984). In these studies, recipient mice infused with $\mathrm{T}$ cells from UV-irradiated mice were unable to reject UV-induced tumors (Fisher \& Kripke, 1977; Kripke \& Fisher, 1976; Kripke et al., 1977; Spellman \& Daynes, 1977; Spellman et al., 1977), but not non-UV-induced tumors such as tumors induced by chemical carcinogen (Hostetler et al., 1989; Kripke et al., 1979; Roberts et al., 1982; Spellman \& Daynes, 1984; Ullrich \& Kripke, 1984), suggesting some degree of antigen-specificity. Subsequent studies using a CHS model further delineated antigenspecific immune suppression by $\mathrm{T}$ cells from UV-irradiated hosts. Upon adoptive transfer with $\mathrm{T}$ cells obtained from mice that had been treated with a hapten onto UV-exposed skin, the recipient mice were no-longer responsive to the very same hapten; however, these recipient mice could respond normally to other unrelated haptens (Elmets et al., 1983). These results convincingly demonstrated that $\mathrm{T}$ cells mediate UV-induced immunosuppression in an antigen-specific manner. Consequently, these $\mathrm{T}$ cells were designated as suppressor $\mathrm{T}$ cells, and have since been renamed regulatory $\mathrm{T}$ cells (Beissert et al., 2006). Even then these early experiments suggested that variations in these regulatory $\mathrm{T}$ cell populations might exist depending on the experimental systems used to induce and examine the UV-induced immunosuppression. Although the lack of clear markers that define a specific subset of $\mathrm{T}$ cells still impedes the attempts to fully characterize UV-induced regulatory $\mathrm{T}$ cells, recent studies have demonstrated that $\mathrm{UV}$-induced regulatory $\mathrm{T}$ cells include $\mathrm{CD}^{+} \mathrm{DX} 5^{+} \mathrm{NKT}$ cells (Moodycliffe et al., 2000); $\mathrm{CD} 4^{+} \mathrm{CD} 25^{+} \mathrm{T}$ cells co-expressing CTLA-4, GITR, and neuropilin-1 (Maeda et al., 2008); CD4+Foxp3+ T cells (Ghoreishi \& Dutz, 2006; Loser et al., 2006); and type 1 regulatory T cells (Hori et al., 2008; Toda et al., 2010; Wang et al., 2010; Wang et al., 2008).

NK-T cells. The CD1d molecules are structurally similar to MHC class I molecules that presents lipid antigens to NKT cells (Brigl \& Brenner, 2004). Moodycliffe et al. have demonstrated that CD1d-deficient mice are resistant to UV-induced immune suppression (Moodycliffe et al., 2000). Adoptive transfer of a purified population of CD3+DX5+ NKT cells from UV-irradiated wild-type mice, which produced high amount of IL-4, into normal syngeneic mice suppressed antigen-specific delayed type hypersensitivity and anti-tumor immune responses against transplanted highly immunogenic UV-induced skin tumors. Subsequent study also revealed that CD1d-deficient mice are resistant to UV-induced skin carcinogenesis (Matsumura et al., 2005). Although, the observed resistant characteristics of CD1d-deficient mice to UV-induced skin carcinogenesis may not be solely due to the lack of NKT cells, these results indicate that UV irradiation induced immunosuppressive NKT cells that may promote tumor development. Recently, it has been shown that epidermal Langerhans cells (LCs) are responsible for the induction of immunosuppressive NKT cell by UV radiation (Fukunaga et al., 2010). UV radiation activates migration of LCs to the skin draining lymph nodes. Adoptive transfer of LCs from the lymph node of UV-irradiated mice into wild-type mice, but not CD1d-deficient mice, resulted in antigen-specific immunosuppression. This study highlights the recent notion that LCs may not play a major role in cutaneous immune responses, but rather regulate immunity in infection and CHS, and play an important role in UV-induced immunosuppression. It has been well documented that the immunosuppressive mechanisms of action of NKT cells remains less clear, but appears to be dependent on IL-4, since immune suppression in mice transferred with LCs from UV-irradiated mice were completely blocked by neutralization of IL-4. However, how NKT cells in UV-irradiated host suppress anti-tumor immune responses remain largely unknown. 
CD25 $^{+}$regulatory T cells. It was not until 1985 that Sakaguchi et al. resurrected the suppressor $\mathrm{T}$ cells, now renamed regulatory $\mathrm{T}$ cells, following almost two decades of abandonment in the field of immunology (Sakaguchi et al., 2007). First characterization of this $\mathrm{T}$ cell subset revealed that they constitutively expressed CD25 and suppressed autoimmunity. The current explosive developments in the field of regulatory $\mathrm{T}$ cells have shown that $\mathrm{CD} 25^{+} \mathrm{CD} 4{ }^{+}$regulatory $\mathrm{T}$ cells express the cell surface molecules such as CTLA4, neurophilin-1, and folate receptor, and Foxp3 transcription factor. The findings at the cellular and molecular levels altogether provide firm evidence for their crucial roles in the establishment and maintenance of immunologic self-tolerance and immune homeostasis (Sakaguchi et al., 2007). Furthermore, it is increasingly clear that CD $25^{+} \mathrm{CD} 4{ }^{+} \mathrm{Foxp} 3^{+}$ regulatory $\mathrm{T}$ cells play an important role in the suppression of anti-tumor immune responses (Nishikawa et al., 2008; Nishikawa et al., 2003; Nishikawa et al., 2005; Nishikawa et al., 2005). Importantly, we have shown that $\mathrm{CD} 25^{+} \mathrm{CD} 4{ }^{+} \mathrm{Foxp} 3^{+}$regulatory $\mathrm{T}$ cells significantly accelerate tumor development in a chemical carcinogen-induced primary tumor development model (Nishikawa et al., 2005). Recent studies revealed that $\mathrm{CD}_{25}{ }^{+} \mathrm{CD} 4{ }^{+} \mathrm{Foxp}^{+}$regulatory $\mathrm{T}$ cells were also involved in the UV-induced immunosuppression. Loser et al. have demonstrated that receptor activator of NF- $\mathrm{B}$ (RANK) and its ligand, RANKL, were involved in UV-induced immunosuppression via activation and/or expansion of $\mathrm{CD} 25^{+} \mathrm{CD} 4{ }^{+} \mathrm{Foxp}^{+}$regulatory $\mathrm{T}$ cells (Loser et al., 2006). They showed that UV irradiation induced the expression of RANKL on basal keratinocytes. Injection of specific RANKL antagonist, RANK-Fc, followed by UV irradiation and hapten immunization resulted in the abrogation of UV-induced hapten-specific immune suppression. Finally, it was found that RANK-RANKL signaling between RANKexpressing LCs and RANKL-overexpressing keratinocytes driven by K14 promoter transgenic mice resulted in the increased capacity of LCs to stimulate the proliferation of $\mathrm{CD}_{25}{ }^{+} \mathrm{CD} 4{ }^{+}{ }^{+} \operatorname{oxp}^{+}$regulatory $\mathrm{T}$ cells. LCs stimulated by RANKL exhibit elevated expression of DEC205 and CD86 as well as increased IL-10 secretion, all of which have been shown to be associated with the DC-induced expansion of regulatory T cells (Loser et al., 2006; Mahnke et al., 2003; Maurer et al., 2003). In the study of Ghoreishi et al., transcutaneous immunization through UV-irradiated skin induced an increase in $\mathrm{CD}_{25}{ }^{+} \mathrm{CD} 4{ }^{+} \mathrm{Foxp}^{+}$regulatory $\mathrm{T}$ cells that suppressed $\mathrm{CTL}$ responses against tumors (Ghoreishi \& Dutz, 2006). In this study, IL-10 was not required for the induction and suppressive function of $\mathrm{CD} 25^{+} \mathrm{CD} 4{ }^{+}$Foxp $3^{+}$regulatory $\mathrm{T}$ cells. Such $\mathrm{T}$ cells were induced in IL-10-deficient mice and these regulatory $\mathrm{T}$ cells conferred suppression of immune responses upon transfer into IL-10-sufficient, but not IL-10-deficient mice. Therefore, it is suggested that $\mathrm{UV}$-irradiation induces $\mathrm{CD} 25{ }^{+} \mathrm{CD} 4{ }^{+} \mathrm{Foxp} 3{ }^{+}$regulatory $\mathrm{T}$ cells independently of IL-10 expression, but these UV-induced regulatory T cells require IL-10 derived from other type of cells, in order to mediate anti-tumor immune responses and support tumor development in UV-irradiated hosts.

IL-10 producing regulatory $\mathbf{T}$ cells. Schwarz and colleagues have conducted a series of studies to characterize UV-induced regulatory T cells using a CHS model. In their studies, UV-induced regulatory $\mathrm{T}$ cells that confer suppression of $\mathrm{CHS}$ belong to the $\mathrm{CD} 4{ }^{+} \mathrm{CD} 25^{+}$ subtype (Schwarz et al., 2004); co-express CTLA-4, GITR, and neuropilin-1 (Maeda et al., 2008; Schwarz et al., 2000); and bind the lectin dectin-2 (Aragane et al., 2003). While most of these phenotypic features are similar to $\mathrm{CD} 25^{+} \mathrm{CD} 4{ }^{+} \mathrm{Foxp} 3^{+}$regulatory $\mathrm{T}$ cells, these UVinduced regulatory $\mathrm{T}$ cells produced large amounts of IL-10 that mediates immunosuppression. Additionally, these UV-induced regulatory T cells exerted bystander 
suppression via the release of IL-10. These characteristics collectively indicate that this regulatory $\mathrm{T}$ cell subset belongs to Tr1 originally described by Groux et al. (Groux et al., 1997; Roncarolo et al., 2006; Vieira et al., 2004). The same group has also demonstrated that IL-10 negatively regulates CTL responses in UV-irradiated mice, which was associated with enhanced tumor growth (Loser et al., 2007). CD4 ${ }^{+} \mathrm{CD} 25^{+} \mathrm{T}$ cells from UV-irradiated wildtype mice, but not those from UV-irradiated IL-10 deficient mice, could transfer the suppression of anti-tumor immune responses (Loser et al., 2007). Therefore, it is highly likely that UV-induced regulatory $\mathrm{T}$ cells reported by Schwarz et al. may also promote tumor development through production of IL-10. It appears that LCs with DNA-damage play an important role in the induction of this type of UV-induced regulatory T cells, since reduction of LCs containing CPDs in the regional lymph nodes by IL-12 prevented the development of UV-induced regulatory T cells. The effect of IL-12 on the prevention of UVinduced regulatory $\mathrm{T}$ cell development was not seen in mice deficient for DNA-repair enzymes.

\section{UV radiation may induce tumor antigen-specific immune suppression thus contributing to the progression of emerging tumors}

In most studies dealing with UV-induced immunosuppression and its impact on anti-tumor immunity, hosts are exposed to UV radiation before immunization, and only a few studies have examined the effect of UV irradiation on established immune responses (Nghiem et al., 2001; Nghiem et al., 2002; Ullrich et al., 2007). Based on the potent immunosuppressive effects of UV irradiation on a variety of immune responses, there is a high likelihood that it affects the efficacy of immune protection afforded by prior vaccination but may also provide tools to develop new therapies for allergic diseases and transplantation. Furthermore, it is also possible that exposure to UV radiation in hosts whose immunity is successfully controlling benign or premalignant tumors may induce tumor-specific immunosuppression and contribute to the development of clinically apparent tumors. In a series of studies, we have demonstrated that mice exposed to UV radiation one week after immunization exhibited reduced Th1- and Th2-driven Ab responses, suppressed airway inflammation in sensitized mice, and prolonged allograft survival in an Ag-specific manner (Hori et al., 2008; Wang et al., 2010; Wang et al., 2008). Additionally, we showed that UV irradiation following immunization led to the generation of $\mathrm{CD}^{+}$regulatory $\mathrm{T}$ cells producing IL-10 and IFN- $\gamma$, and Ag-dependent secretion of IL-10 was responsible for the immunosuppression. These phenotypic and functional features were reminiscent of Tr1. However, CD4 ${ }^{+} \mathrm{T}$ cells from UV-irradiated mice contained Foxp $3^{+} \mathrm{T}$ cells lacking IL-10 expression (Wang et al., 2008). Recently, we generated a panel of T cell clones from UV-irradiated mice and examined their functional and phenotypic characteristics to better characterize the immunosuppressive cells. All of the T cell clones derived from UV-irradiated mice produced both IL-10 and IFN$\gamma$, but not IL-4, and this strongly argues that a general shift of immunity from a Th1- to Th2type immune response is not responsible for the UV-induced immune suppression (Beissert et al., 1996; Shreedhar et al., 1998). Notably, the T cell clones derived from UV-irradiated mice lacked expression of Foxp3 mRNA, but they uniformly expressed c-Maf mRNA. c-Maf was originally described as a Th2-specific transcription factor, but subsequent studies revealed that c-Maf transactivates IL-10 gene transcription independently of Th2 differentiation (Cao et al., 2005; Xu et al., 2009). More recent studies indicate that c-Maf transactivates IL-21, which acts as an autocrine growth factor for the expansion and/or 
maintenance of Tr1 cells (Apetoh et al., 2010; Pot et al., 2009). Although Th2 cells express cMaf, it has also been shown that the expression levels of c-Maf mRNA are $~ 500$-fold higher in Tr1 cells compared to Th2 cells (Pot et al., 2009). Therefore, c-Maf now can be regarded as a critical transcription factor for Tr1 cells. In addition, T cell clones from UV-irradiated mice exerted Ag-specific and bystander suppression of T cell activation in an IL-10-dependent but a contact-independent fashion. Taken together, these results indicate that UV-induced regulatory $\mathrm{T}$ cell subsets involve Tr1. We also found that IL-10 was required for the development of this regulatory $\mathrm{T}$ cell subset. $\mathrm{CD} 4^{+} \mathrm{T}$ cells from $\mathrm{UV}$-irradiated mice treated with anti-IL-10 no longer have immunosuppressive properties, clearly indicating that IL-10 is necessary for UV-induced regulatory T cells. Consistent with others, IL-10 is detectable in serum of mice exposed to UV radiation at dose of 15 or $30 \mathrm{~kJ} / \mathrm{m}^{2}$ (Beissert et al., 1996; Rivas \& Ullrich, 1994; Shreedhar et al., 1998). In addition, treating UV-irradiated mice with anti-IL10 has been reported to block the induction of systemic immune suppression (Rivas \& Ullrich, 1992), which substantiates our results that neutralization of IL-10 suppresses the generation and function of regulatory $\mathrm{T}$ cells induced by UV-irradiation. Therefore, IL-10 that was possibly secreted by keratinocytes upon UV-irradiation (Rivas \& Ullrich, 1992) appeared to play an obligatory role in the generation of Tr1-like regulatory $\mathrm{T}$ cells that mediated suppression of variety of immune responses. Although the precise mechanism by which UV induces Tr1-like regulatory $\mathrm{T}$ cells in vivo remains elusive, our preliminary experiments indicated that the effect of IL-10 induced by UV-irradiation on the generation of Tr1-like regulatory $\mathrm{T}$ cells was not a direct effect on $\mathrm{T}$ cells, because repetitive stimulation of $\mathrm{CD}^{+} \mathrm{T}$ cells by anti-CD3 together with IL-10 in the presence, but not absence, of APC resulted in the generation of IL-10 producing Tr1-like regulatory $\mathrm{T}$ cells in vitro. These results confirm previous studies showing that IL-10 modulates APC and/or induces differentiation of CD11clow CD45RBhigh DCs required to induce the generation of Tr1 in vitro and in vivo (Wakkach et al., 2001; Wakkach et al., 2003). However, it remains elusive whether UV induces such phenotypic changes or generation of such DCs. Importantly, using a murine tumor model in which ovalbumin (OVA) served as a surrogate tumor Ag, we demonstrated that exposure to UV radiation in OVA-immunized mice significantly accelerated the acceptance of the tumor as compared to those exposed to UV radiation alone, which is mediated antigen-specific regulatory $\mathrm{T}$ cells mentioned above. We also showed that these regulatory $\mathrm{T}$ cells suppress the induction and/or activation of cytotoxic $\mathrm{T}$ cells. All these results indicate that UV-irradiation after immunization induces Tr1 cells specific to the immunizing Ag and dominantly suppresses a variety of immune responses that control tumor progression. Accumulating evidence indicates that precancerous and malignant cells can induce specific immune response that leads to the elimination of malignant and/or transformed cell before they developed detectable tumors. Furthermore, recent multivariate analysis of a multi-country ecological study and population based, casecontrol study have shown a significant positive association between exposure to UV radiation and increase in the risks of non-Hodgkin's lymphoma and colon cancer, in addition to skin melanoma (Waltz \& Chodick, 2008; Zhang et al., 2007). Even in the case with melanomas, some melanomas arise at such as palms, soles, and mucosal surfaces, which do not have obvious exposure to UV (Garibyan \& Fisher, 2010). Therefore, it appears plausible that exposure to UV radiation in hosts whose immunity successfully controlling benign or premalignant tumors induces tumor-specific immunosuppression and contributes to tumor progression. In this regard, UV-induced immune suppression may also play an important role in the progression of various tumors, including some in which UV radiation does not play a direct causative role. 


\section{Molecules that trigger UV-induced immunosuppression}

Immunologic reactions are evoked by an intricate network of signaling and cell activation. Therefore, UV-induced immunosuppression may also have evolved under the influence of altered molecules expressed in cells damaged by UV radiation. As is the case with a major role of DNA-damage played in the initiation of carcinogenesis, accumulating evidence indicates that UV-induced DNA-damage is an important trigger for UV-induced immunosuppression. The topical application of exogenous DNA repair enzymes to UVirradiated skin has been shown to reduce UV-induced DNA-damage and resulted in the abrogation of UV-induced immunosuppression (Applegate et al., 1989; Kripke et al., 1992). Consistent with this finding, it has been shown that DNA-damage induced by the treatment of mice with HindIII-containing liposomes causes double-strand breaks and induces immunosuppression (Nishigori et al., 1998). Likewise, deficiency in DNA repair in XPA (xeroderma pigmentosum group A)-gene knockout mice exhibits enhanced susceptibility to UV-induced immunosuppression (Miyauchi-Hashimoto et al., 1996). IL-12 was the first cytokine being demonstrated to exert the capacity to prevent UV-induced immunosuppression (Muller et al., 1995; Schmitt et al., 1995; Schwarz et al., 1996). Because of its well-recognized immunostimulatory activities (Trinchieri, 2003), it was no wonder that exogenous administration of IL-12 recovered the immunosuppressive effects of UV radiation. However, recent studies unravel an unexpected capacity of IL-12 to reduce DNAdamage via induction or activation of the nucleotide excision repair (NER), the major endogenous DNA repair system (Schwarz et al., 2002). It has been demonstrated that IL-12 is unable to prevent UV-induced immunosuppression in mice deficient for NER (Schwarz et al., 2005). Using mouse models, the additional factors that influence the NER and reverse UV-induced immunosuppression have been demonstrated, including IL-18 (Schwarz et al., 2006), IL-23 (Majewski et al.), a-melanocyte-stimulating hormone (Bohm et al., 2005), infrared radiation (Jantschitsch et al., 2009), vitamin D (Tremezaygues et al., 2009), and even UV-A (Garssen et al., 2001) possibly through the induction of IL-12 (Shen et al., 1999); however, their relevance in human subjects remains to be determined. Although UV radiation induces different types of DNA lesions such as CPDs and 6-4PPs along with its isomeric secondary product, Dewar valence isomer, it was later found that repair of 6-4PPs had no effect on UV-induced immunosuppression (Jans et al., 2006). Using mice expressing the $P$. tridacylus CPD photolylase enzyme under the control of the basal keratinocyte-specific promoter keratin-14, which allows rapid, light-dependent removal of CPDs from basal keratinocytes only, it was demonstrated that removal of CPDs solely from basal epidermal cells in transgenic mice resulted in a major reduction in UV-induced carcinogenesis, but did not reverse UV-induced immunosuppression, whereas the removal from the entire skin reversed UV-induced immunosuppression (Jans et al., 2006). UV-induced DNA-damage in different cell types independently mediates carcinogenic or immunosuppressive properties of UV radiation. Collectively, these studies convincingly demonstrate that DNA-damage, especially in the form of CPDs, is a major molecular trigger in UV-induced immunosuppression.

In addition to CPDs, UV radiation induces the formation of cis-urocanic acid (cis-UCA) from its isomer trans-UCA. Trans-UCA is abundant in the skin because of the lack of the necessary enzymes in epidermal cells to catabolize UCA generated in the metabolic pathway of the essential amino acid histidine. Injection of cis-UCA (Beissert et al., 1997; De Fabo \& Noonan, 1983; Norval et al., 1995) induces immunosuppression, whereas its removal 
by epidermal stripping, neutralization by antibodies, or blocking the binding to its receptor $\left(5-\mathrm{HT}_{2 \mathrm{~A}}\right)$ with selective serotonin receptor antagonists, restores immune suppression induced by UV radiation (De Fabo \& Noonan, 1983; Moodycliffe et al., 1996; Walterscheid et al., 2006). It also has been shown that neutralization of cis-UCA in vivo suppressed UVinduced carcinogenesis (Beissert et al., 2001). Despite all these documented abilities of cisUCA to influence immune suppression and carcinogenesis, recent studies demonstrated that cis-UCA induces apoptosis in several human tumor cells including melanomas (Laihia et al., 2010; Laihia et al., 2009; Peuhu et al., 2010), and cis-UCA has been recognized as a potential anti-cancer agent.

Nevertheless, CPDs and cis-UCA, abundant molecules in UV-irradiated skin, are responsible for UV-induced immunosuppression. These molecules have been shown to induce cytokines such as IL-10, PGE2, and TGF- $\beta$ (Curiel-Lewandrowski et al., 2003; Grewe et al., 2000; Kaneko et al., 2008; Kaneko et al., 2009; Nishigori et al., 1996), all of which may be involved in the development and/or activation of cells with regulatory activities (Allan et al., 2008). However, what still remains elusive is how these molecules induce various types of regulatory $\mathrm{T}$ cells that mediate antigen-specific and systemic immunosuppression.

\section{Conclusion}

Over the decades, it has become clear that UV irradiation has the potential to suppress a variety of immune reactions including anti-tumor immune responses through the generation of antigen-specific regulatory $\mathrm{T}$ cells. The concepts of 'regulatory $\mathrm{T}$ cells' and 'immune control of tumor' have experienced a very eventful past having been dogmatically disregarded and abandoned but being now highly appreciated and well recognized by the majority of immunologists. Major credit can be given to the researchers in the field of photoimmunology who persistently pursued and accumulated evidence supporting both concepts. However, it seems that the importance or physiological relevance of UV-induced skin cancers, wherein the existence of cancer immunity and regulatory $\mathrm{T}$ cells are so obvious, has never been established as a prominent model in the field of tumor immunology and immunology in general. As may be seen in this chapter, it is now quite clear that UV radiation plays an indisputable role in skin carcinogenesis, as a tumor initiator and progressor, and also in the development of cancer wherein UV radiation does not play a causative role.

Recent studies have begun to unravel the differential effects of UV radiation on the innate and the adaptive immune system (Schwarz, 2010). Although UV irradiation clearly suppresses adaptive immunity, it may activate innate immunity. It has been shown that only $30-50 \%$ of UVR doses that induced detectable sunburn are required for the suppression of immunity in humans, and therefore normal daily outdoor activities are likely to cause some degree of immunosuppression. Understanding that the skin is an organ that seems quite prone to autoimmunity, it is plausible that a certain degree of immunosuppression by daily solar exposure may be protective against autoimmunity, and that activation of innate immunity may compensate for the increased risks of microbial infection by suppression of adaptive immunity, which may function as a part of the protection mechanism acquired during evolution. This may argue against total sun protection for the sake of skin cancer prevention. Additionally, patients with allergic diseases that also receive benefit from UVphototherapy may be through the induction of regulatory $T$ cells (Wang, 2010). Thus, despite the fact that excessive and chronic UV radiation exposure remains one of the major 
environmental threats for human health, a better understanding of carcinogenic and immunosuppressive properties of UV radiation, and its underlying mechanisms is needed for the prevention and cure of skin cancer, but also for formulating therapeutic use of UV and future sun protection strategy.

\section{Acknowledgements}

The authors are very grateful to Dr. Kagemasa Kuribayashi for his insightful advice and encouragement that permit us to pursue the projects related to this review. The authors also thank Dr. Hiroshi Shiku for his continuous support. This work was supported in part by grants from Grant-in-Aid for Scientific Research (C) by the Ministry of Education, Culture, Sports, Science and Technology of Japan; and Long-range Research Initiative (LRI) by Japan Chemical Industry Association (JCIA, Tokyo, Japan) to T.K.

\section{References}

Aberg, F.; Pukkala, E.; Höckerstedt, K.; Sankila, R. \& Isoniemi, H. (2008). Risk of malignant neoplasms after liver transplantation: a population-based study. Liver Transpl, Vol.14, No.10, (October 2008), pp. 1428-36, ISSN1527-6473

Allan, S.E.; Broady, R.; Gregori, S.; Himmel, M.E.; Locke, N.; Roncarolo, M.G.; Bacchetta, R. \& Levings, M.K. (2008). CD4 ${ }^{+}$T-regulatory cells: toward therapy for human diseases. Immunol Rev, Vol.223, (June 2008), pp. 391-421, ISSN 1600-065X

Apetoh, L.; Quintana, F.J.; Pot, C.; Joller, N.; Xiao, S.; Kumar, D.; Burns, E.J.; Sherr, D.H.; Weiner, H.L. \& Kuchroo, V.K. (2010). The aryl hydrocarbon receptor interacts with c-Maf to promote the differentiation of type 1 regulatory T cells induced by IL-27. Nat Immunol, Vol.11, No.9, (Sepember 2010), pp. 854-61, ISSN 1529-2916

Applegate, L.A.; Ley, R.D.; Alcalay, J. \& Kripke, M.L. (1989). Identification of the molecular target for the suppression of contact hypersensitivity by ultraviolet radiation. J Exp Med, Vol.170, No.4, (October 1989), pp. 1117-31, ISSN 0022-1007

Aragane, Y.; Maeda, A.; Schwarz, A.; Tezuka, T.; Ariizumi, K. \& Schwarz, T. (2003). Involvement of dectin-2 in ultraviolet radiation-induced tolerance. J Immunol, Vol.171, (September 2003), pp. 3801-7, ISSN 0022-1767

Bartel, D.P. (2004). MicroRNAs: genomics, biogenesis, mechanism, and function. Cell, Vol.116, No.2, (January 2004), pp. 281-97, ISSN 0092-8674

Beissert, S.; Hosoi, J.; Kuhn, R.; Rajewsky, K.; Muller, W. \& Granstein, R.D. (1996). Impaired immunosuppressive response to ultraviolet radiation in interleukin-10-deficient mice. J Invest Dermatol, Vol.107, (October 1996), pp. 553-7, ISSN 0022-202X

Beissert, S.; Mohammad, T.; Torri, H.; Lonati, A.; Yan, Z.; Morrison, H. \& Granstein, R.D. (1997). Regulation of tumor antigen presentation by urocanic acid. I Immunol, Vol.159, No.1, (July 1997), pp. 92-6, ISSN 0022-1767

Beissert, S.; Ruhlemann, D.; Mohammad, T.; Grabbe, S.; El-Ghorr, A.; Norval, M.; Morrison, H.; Granstein, R.D. \& Schwarz, T. (2001). IL-12 prevents the inhibitory effects of cisurocanic acid on tumor antigen presentation by Langerhans cells: implications for photocarcinogenesis. J Immunol, Vol.167, No.11, (December 2001), pp. 6232-8, ISSN 0022-1767 
Beissert, S.; Schwarz, A. \& Schwarz, T. (2006). Regulatory T cells. J Invest Dermatol, Vol.126, No.1, (January 2006), pp. 15-24, ISSN 0022-202X

Besaratinia, A. \& Pfeifer, G.P. (2008). Sunlight ultraviolet irradiation and BRAF V600 mutagenesis in human melanoma. Hum Mutat, Vol.29, No.8, (Aug 2008), pp. 983-91, ISSN 1098-1004

Bohm, M.; Wolff, I.; Scholzen, T.E.; Robinson, S.J.; Healy, E.; Luger, T.A.; Schwarz, T. \& Schwarz, A. (2005). alpha-Melanocyte-stimulating hormone protects from ultraviolet radiation-induced apoptosis and DNA damage. J Biol Chem, Vol.280, No.7, (February 2005), pp. 5795-802, ISSN 0021-9258

Boshoff, C. \& Weiss, R. (2002). AIDS-related malignancies. Nat Rev Cancer, Vol.2, No.5, (May 2002), pp. 373-82, ISSN 1474-175X

Brash, D.E.; Rudolph, J.A.; Simon, J.A.; Lin, A.; McKenna, G.J.; Baden, H.P.; Halperin, A.J. \& Ponten, J. (1991). A role for sunlight in skin cancer: UV-induced p53 mutations in squamous cell carcinoma. Proc Natl Acad Sci U S A, Vol.88, No.22, (November 1991), pp. 10124-8, ISSN 0027-8424

Brigl, M. \& Brenner, M.B. (2004). CD1: antigen presentation and T cell function. Annu Rev Immunol, Vol.22, 2004), pp. 817-90, ISSN 0732-0582

Cao, S.; Liu, J.; Song, L. \& Ma, X. (2005). The protooncogene c-Maf is an essential transcription factor for IL-10 gene expression in macrophages. J Immunol, Vol.174, No.6, (March 2005), pp. 3484-92, ISSN 0022-1767

Catto, J.W.; Alcaraz, A.; Bjartell, A.S.; De Vere White, R.; Evans, C.P.; Fussel, S.; Hamdy, F.C.; Kallioniemi, O.; Mengual, L.; Schlomm, T. \& Visakorpi, T. (2011). MicroRNA in Prostate, Bladder, and Kidney Cancer: A Systematic Review. Eur Urol, Vol.59, No.5, (May 2011), pp. 671-81, ISSN 1873-7560

Chan, J.; Robinson, E.S.; Yeh, I.T. \& McCarrey, J.R. (2002). Absence of ras gene mutations in UV-induced malignant melanomas correlates with a dermal origin of melanocytes in Monodelphis domestica. Cancer Lett, Vol.184, No.1, (October 2002), pp. 73-80, ISSN 0304-3835

Chaturvedi, A.K.; Pfeiffer, R.M.; Chang, L.; Goedert, J.J.; Biggar, R.J. \& Engels, E.A. (2007). Elevated risk of lung cancer among people with AIDS. AIDS, Vol.21, No.2, (January 2007), pp. 207-13, ISSN 0269-9370

Clingen, P.H.; Arlett, C.F.; Roza, L.; Mori, T.; Nikaido, O. \& Green, M.H. (1995). Induction of cyclobutane pyrimidine dimers, pyrimidine(6-4)pyrimidone photoproducts, and Dewar valence isomers by natural sunlight in normal human mononuclear cells. Cancer Res, Vol.55, No.11, (June 1995), pp. 2245-8, ISSN 0008-5472

Curiel-Lewandrowski, C.; Venna, S.S.; Eller, M.S.; Cruikshank, W.; Dougherty, I.; Cruz, P.D., Jr. \& Gilchrest, B.A. (2003). Inhibition of the elicitation phase of contact hypersensitivity by thymidine dinucleotides is in part mediated by increased expression of interleukin-10 in human keratinocytes. Exp Dermatol, Vol.12, No.2, (Apr 2003), pp. 145-52, 0906-6705

D'Errico, M.; Calcagnile, A.; Canzona, F.; Didona, B.; Posteraro, P.; Cavalieri, R.; Corona, R.; Vorechovsky, I.; Nardo, T.; Stefanini, M. \& Dogliotti, E. (2000). UV mutation signature in tumor suppressor genes involved in skin carcinogenesis in xeroderma pigmentosum patients. Oncogene, Vol.19, No.3, (Januart 2000), pp. 463-7, ISSN 09509232 
Daya-Grosjean, L. \& Sarasin, A. (2000). UV-specific mutations of the human patched gene in basal cell carcinomas from normal individuals and xeroderma pigmentosum patients. Mutat Res, Vol.450, No.1-2, (May 2000), pp. 193-9, ISSN 0027-5107

De Fabo, E.C. \& Noonan, F.P. (1983). Mechanism of immune suppression by ultraviolet irradiation in vivo. I. Evidence for the existence of a unique photoreceptor in skin and its role in photoimmunology. J Exp Med, Vol.158, No.1, (July 1983), pp. 84-98, ISSN 0022-1007

de Gruiji, F.R. \& van der Leun, J.C. (1982). Systemic influence of pre-irradiation of a limited skin area on UV-tumorigenesis. Photochem Photobiol, Vol.35, No.3, (March 1982), pp. 379-83, ISSN 0031-8655

de Gruijl, F.R. \& Rebel, H. (2008). Early events in UV carcinogenesis--DNA damage, target cells and mutant p53 foci. Photochem Photobiol, Vol.84, No.2, (Mach 2008), pp. 382-7, ISSN 0031-8655

de Gruijl, F.R. \& Van Der Leun, J.C. (1983). Follow up on systemic influence of partial preirradiation on UV-tumorigenesis. Photochem Photobiol, Vol.38, No.3, (September 1983), pp. 381-3, ISSN 0031-8655

de Gruijl, F.R.; van Kranen, H.J. \& Mullenders, L.H. (2001). UV-induced DNA damage, repair, mutations and oncogenic pathways in skin cancer. J Photochem Photobiol B, Vol.63, No.1-3, (October 2001), pp. 19-27, ISSN 1011-1344

DeFabo, E.C. \& Kripke, M.L. (1979). Dose-response characteristics of immunologic unresponsiveness to UV-induced tumors produced by UV irradiation of mice. Photochem Photobiol, Vol.30, No.3, (September 1979), pp. 385-90, ISSN 0031-8655

Diffey, B.L. (2002). Sources and measurement of ultraviolet radiation. Methods, Vol.28, No.1, (September 2002), pp. 4-13, ISSN 1046-2023

Dighe, A.S.; Richards, E.; Old, L.J. \& Schreiber, R.D. (1994). Enhanced in vivo growth and resistance to rejection of tumor cells expressing dominant negative IFN $\gamma$ receptors. Immunity, Vol.1, No.6, (September 1994), pp. 447-56, ISSN 1074-7613

Douki, T.; Perdiz, D.; Grof, P.; Kuluncsics, Z.; Moustacchi, E.; Cadet, J. \& Sage, E. (1999). Oxidation of guanine in cellular DNA by solar UV radiation: biological role. Photochem Photobiol, Vol.70, No.2, (August 1999), pp. 184-90, ISSN 0031-8655

Douki, T.; Reynaud-Angelin, A.; Cadet, J. \& Sage, E. (2003). Bipyrimidine photoproducts rather than oxidative lesions are the main type of DNA damage involved in the genotoxic effect of solar UVA radiation. Biochemistry, Vol.42, No.30, (August 2003), pp. 9221-6, ISSN 0006-2960

Dziunycz, P.; Iotzova-Weiss, G.; Eloranta, J.J.; Lauchli, S.; Hafner, J.; French, L.E. \& Hofbauer, G.F. (2010). Squamous cell carcinoma of the skin shows a distinct microRNA profile modulated by UV radiation. J Invest Dermatol, Vol.130, No.11, (November 2010), pp. 2686-9, ISSN 1523-1747

Elmets, C.A.; Bergstresser, P.R.; Tigelaar, R.E.; Wood, P.J. \& Streilein, J.W. (1983). Analysis of the mechanism of unresponsiveness produced by haptens painted on skin exposed to low dose ultraviolet radiation. J Exp Med, Vol.158, No.3, (September 1983), pp. 781-94, ISSN 0022-1007

Ely, J.O. \& Ross, M.H. (1949). Absorption of ultraviolet light by living cells. Nature, Vol.163, No.4154, (June 1949), pp. 906, ISSN 0028-0836 
Fisher, M.S. \& Kripke, M.L. (1977). Systemic alteration induced in mice by ultraviolet light irradiation and its relationship to ultraviolet carcinogenesis. Proc Natl Acad Sci USA, Vol.74, No.4, (April 1977), pp. 1688-92, ISSN 0027-8424

Frisch, M.; Biggar, R.J.; Engels, E.A.; Goedert, J.J. \& Group, A.-C.M.R.S. (2001). Association of cancer with AIDS-related immunosuppression in adults. JAMA, Vol.285, No.13, (April 2001), pp. 1736-45, ISSN 0098-7484

Fukunaga, A.; Khaskhely, N.M.; Ma, Y.; Sreevidya, C.S.; Taguchi, K.; Nishigori, C. \& Ullrich, S.E. (2010). Langerhans cells serve as immunoregulatory cells by activating NKT cells. J Immunol, Vol.185, No.8, (October 2010), pp. 4633-40, ISSN 1550-6606

Gaddameedhi, S.; Kemp, M.G.; Reardon, J.T.; Shields, J.M.; Smith-Roe, S.L.; Kaufmann, W.K. \& Sancar, A. (2010). Similar nucleotide excision repair capacity in melanocytes and melanoma cells. Cancer Res, Vol.70, No.12, (June 2010), pp. 4922-30, ISSN 1538-7445

Garibyan, L. \& Fisher, D.E. (2010). How sunlight causes melanoma. Curr Oncol Rep, Vol.12, No.5, (Sepember 2010), pp. 319-26, ISSN 1534-6269

Garssen, J.; de Gruijl, F.; Mol, D.; de Klerk, A.; Roholl, P. \& Van Loveren, H. (2001). UVA exposure affects UVB and cis-urocanic acid-induced systemic suppression of immune responses in Listeria monocytogenes-infected Balb/c mice. Photochem Photobiol, Vol.73, No.4, (April 2001), pp. 432-8, ISSN 0031-8655

Ghoreishi, M. \& Dutz, J.P. (2006). Tolerance induction by transcutaneous immunization through ultraviolet-irradiated skin is transferable through $\mathrm{CD} 4{ }^{+} \mathrm{CD} 25^{+} \mathrm{T}$ regulatory cells and is dependent on host-derived IL-10. J Immunol, Vol.176, No.4, (February 2006), pp. 2635-44, ISSN 0022-1767

Ghosh, R.; Amstad, P. \& Cerutti, P. (1993). UVB-induced DNA breaks interfere with transcriptional induction of c-fos. Mol Cell Biol, Vol.13, No.11, (Nov 1993), pp. $6992-$ 9, ISSN 0270-7306

Grewe, M.; Stege, H.; Vink, A.; Klammer, M.; Ruzicka, T.; Roza, L. \& Krutmann, J. (2000). Inhibition of intercellular adhesio nmolecule-1 (ICAM-1) expression in ultraviolet B-irradiated human antigen-presenting cells is restored after repair of cyclobutane pyrimidine dimers. Exp Dermatol, Vol.9, No.6, (December 2000), pp. 423-30, ISSN 0906-6705

Groux, H.; O'Garra, A.; Bigler, M.; Rouleau, M.; Antonenko, S.; de Vries, J.E. \& Roncarolo, M.G. (1997). A CD4+ T-cell subset inhibits antigen-specific T-cell responses and prevents colitis. Nature, Vol.389, (September 1997), pp. 737-42, ISSN 0028-0836

Guo, L.; Huang, Z.X.; Chen, X.W.; Deng, Q.K.; Yan, W.; Zhou, M.J.; Ou, C.S. \& Ding, Z.H. (2009). Differential expression profiles of microRNAs in NIH3T3 cells in response to UVB irradiation. Photochem Photobiol, Vol.85, No.3, (May 2009), pp. 765-73, ISSN 0031-8655

Hanahan, D. \& Weinberg, R.A. (2000). The hallmarks of cancer. Cell, Vol.100, No.1, (Jan 7 2000), pp. 57-70, ISSN 0092-8674

Hanahan, D. \& Weinberg, R.A. (2011). Hallmarks of cancer: the next generation. Cell, Vol.144, No.5, (March 2011), pp. 646-74, ISSN 1097-4172

Harper, J.W. \& Elledge, S.J. (2007). The DNA damage response: ten years after. Mol Cell, Vol.28, No.5, (December 2007), pp. 739-45, ISSN 1097-2765

Harrison, J.C. \& Haber, J.E. (2006). Surviving the breakup: the DNA damage checkpoint. Annu Rev Genet, Vol.40, (June 2006), pp. 209-35, ISSN 0066-4197 
Hoeijmakers, J.H. (2001). Genome maintenance mechanisms for preventing cancer. Nature, Vol.411, No.6835, (May 17 2001), pp. 366-74, ISSN 0028-0836

Holly, E.A.; Aston, D.A.; Cress, R.D.; Ahn, D.K. \& Kristiansen, J.J. (1995). Cutaneous melanoma in women. I. Exposure to sunlight, ability to tan, and other risk factors related to ultraviolet light. Am J Epidemiol, Vol.141, No.10, (May 1995), pp. 923-33, ISSN 0002-9262

Hori, T.; Kuribayashi, K.; Uemoto, S.; Saito, K.; Wang, L.; Torii, M.; Shibutani, S.; Taniguchi, K.; Yagi, S.; Iida, T.; Yamamoto, C. \& Kato, T. (2008). Alloantigen-specific prolongation of allograft survival in recipient mice treated by alloantigen immunization following ultraviolet-B irradiation. Transpl Immunol, Vol.19, No.1, (April 2008), pp. 45-54, ISSN 0966-3274

Hostetler, L.W.; Romerdahl, C.A. \& Kripke, M.L. (1989). Specificity of antigens on UV radiation-induced antigenic tumor cell variants measured in vitro and in vivo. Cancer Res, Vol.49, No.5, (March 1989), pp. 1207-13, ISSN 0008-5472

Hussein, M.R.; Haemel, A.K. \& Wood, G.S. (2003). Apoptosis and melanoma: molecular mechanisms. J Pathol, Vol.199, No.3, (March 2003), pp. 275-88, ISSN 0022-3417

IARC. (1992). IARC monographs on the evaluation of carcinogenic risks to humans. Solar and ultraviolet radiation. IARC Monogr Eval Carcinog Risks Hum, Vol.55, (1992), pp. 1-316, ISSN 1017-1606

Jacinto, F.V. \& Esteller, M. (2007). Mutator pathways unleashed by epigenetic silencing in human cancer. Mutagenesis, Vol.22, No.4, (July 2007), pp. 247-53, ISSN 0267-8357

Jackson, S.P. \& Bartek, J. (2009). The DNA-damage response in human biology and disease. Nature, Vol.461, No.7267, (October 2009), pp. 1071-8, ISSN 1476-4687

Jans, J.; Garinis, G.A.; Schul, W.; van Oudenaren, A.; Moorhouse, M.; Smid, M.; Sert, Y.G.; van der Velde, A.; Rijksen, Y.; de Gruijl, F.R.; van der Spek, P.J.; Yasui, A.; Hoeijmakers, J.H.; Leenen, P.J. \& van der Horst, G.T. (2006). Differential role of basal keratinocytes in UV-induced immunosuppression and skin cancer. Mol Cell Biol, Vol.26, No.22, (November 2006), pp. 8515-26, ISSN 0270-7306

Jans, J.; Schul, W.; Sert, Y.G.; Rijksen, Y.; Rebel, H.; Eker, A.P.; Nakajima, S.; van Steeg, H.; de Gruijl, F.R.; Yasui, A.; Hoeijmakers, J.H. \& van der Horst, G.T. (2005). Powerful skin cancer protection by a CPD-photolyase transgene. Curr Biol, Vol.15, No.2, (January 2005), pp. 105-15, ISSN 0960-9822

Jantschitsch, C.; Majewski, S.; Maeda, A.; Schwarz, T. \& Schwarz, A. (2009). Infrared radiation confers resistance to UV-induced apoptosis via reduction of DNA damage and upregulation of antiapoptotic proteins. J Invest Dermatol, Vol.129, No.5, (May 2009), pp. 1271-9, ISSN 1523-1747

Jiveskog, S.; Ragnarsson-Olding, B.; Platz, A. \& Ringborg, U. (1998). N-ras mutations are common in melanomas from sun-exposed skin of humans but rare in mucosal membranes or unexposed skin. J Invest Dermatol, Vol.111, No.5, (November 1998), pp. 757-61, ISSN 0022-202X

Kaneko, K.; Smetana-Just, U.; Matsui, M.; Young, A.R.; John, S.; Norval, M. \& Walker, S.L. (2008). cis-Urocanic acid initiates gene transcription in primary human keratinocytes. J Immunol, Vol.181, No.1, (July 2008), pp. 217-24, ISSN 0022-1767

Kaneko, K.; Travers, J.B.; Matsui, M.S.; Young, A.R.; Norval, M. \& Walker, S.L. (2009). cisUrocanic acid stimulates primary human keratinocytes independently of serotonin 
or platelet-activating factor receptors. J Invest Dermatol, Vol.129, No.11, (November 2009), pp. 2567-73, ISSN 1523-1747

Kanellou, P.; Zaravinos, A.; Zioga, M.; Stratigos, A.; Baritaki, S.; Soufla, G.; Zoras, O. \& Spandidos, D.A. (2008). Genomic instability, mutations and expression analysis of the tumour suppressor genes p14(ARF), p15(INK4b), p16(INK4a) and p53 in actinic keratosis. Cancer Lett, Vol.264, No.1, (June 2008), pp. 145-61, ISSN 0304-3835

Kaplan, D.H.; Shankaran, V.; Dighe, A.S.; Stockert, E.; Aguet, M.; Old, L.J. \& Schreiber, R.D. (1998). Demonstration of an interferon gamma-dependent tumor surveillance system in immunocompetent mice. Proc Natl Acad Sci U S A, Vol.95, No.13, (June 1998), pp. 7556-61, ISSN 0027-842

Katiyar, S.K. (2007). UV-induced immune suppression and photocarcinogenesis: chemoprevention by dietary botanical agents. Cancer Lett, Vol.255, No.1, (Sepember 2007), pp. 1-11, ISSN 0304-3835

Kielbassa, C.; Roza, L. \& Epe, B. (1997). Wavelength dependence of oxidative DNA damage induced by UV and visible light. Carcinogenesis, Vol.18, No.4, (April 1997), pp. 8116, ISSN 0143-3334

Kreimer-Erlacher, H.; Seidl, H.; Back, B.; Kerl, H. \& Wolf, P. (2001). High mutation frequency at Ha-ras exons 1-4 in squamous cell carcinomas from PUVA-treated psoriasis patients. Photochem Photobiol, Vol.74, No.2, (August 2001), pp. 323-30, ISSN 0031-8655

Kripke, M.L. (1974). Antigenicity of murine skin tumors induced by ultraviolet light. J Natl Cancer Inst, Vol.53, No.5, (November 1974), pp. 1333-6, ISSN 0027-8874

Kripke, M.L.; Cox, P.A.; Alas, L.G. \& Yarosh, D.B. (1992). Pyrimidine dimers in DNA initiate systemic immunosuppression in UV-irradiated mice. Proc Natl Acad Sci U S A, Vol.89, No.16, (August 1992), pp. 7516-20, ISSN 0027-8424

Kripke, M.L. \& Fisher, M.S. (1976). Immunologic parameters of ultraviolet carcinogenesis. J Natl Cancer Inst, Vol.57, No.1, (July 1976), pp. 211-5, ISSN 0027-8874

Kripke, M.L.; Lofgreen, J.S.; Beard, J.; Jessup, J.M. \& Fisher, M.S. (1977). In vivo immune responses of mice during carcinogenesis by ultraviolet irradiation. J Natl Cancer Inst, Vol.59, No.4, (October 1977), pp. 1227-30, ISSN 0027-8874

Kripke, M.L.; Thorn, R.M.; Lill, P.H.; Civin, C.I.; Pazmino, N.H. \& Fisher, M.S. (1979). Further characterization of immunological unresponsiveness induced in mice by ultraviolet radiation. Growth and induction of nonultraviolet-induced tumors in ultraviolet-irradiated mice. Transplantation, Vol.28, No.3, (Sepember 1979), pp. 2127, ISSN 0041-1337

Laihia, J.K.; Kallio, J.P.; Taimen, P.; Kujari, H.; Kahari, V.M. \& Leino, L. (2010). Protodynamic intracellular acidification by cis-urocanic acid promotes apoptosis of melanoma cells in vitro and in vivo. J Invest Dermatol, Vol.130, No.10, (October 2010), pp. 2431-9, ISSN 1523-1747

Laihia, J.K.; Pylkkanen, L.; Laato, M.; Bostrom, P.J. \& Leino, L. (2009). Protodynamic therapy for bladder cancer: in vitro results of a novel treatment concept. BJU Int, Vol.104, No.9, (November 2009), pp. 1233-8, ISSN 1464-410X

Lippke, J.A.; Gordon, L.K.; Brash, D.E. \& Haseltine, W.A. (1981). Distribution of UV lightinduced damage in a defined sequence of human DNA: detection of alkaline- 
sensitive lesions at pyrimidine nucleoside-cytidine sequences. Proc Natl Acad Sci $U$ $S$ A, Vol.78, No.6, (June 1981), pp. 3388-92, ISSN 0027-8424

Livneh, Z. (2006). Keeping mammalian mutation load in check: regulation of the activity of error-prone DNA polymerases by p53 and p21. Cell Cycle, Vol.5, No.17, (September 2006), pp. 1918-22, ISSN 1551-4005

Loeffelbein, D.J.; Szilinski, K. \& Hölzle, F. (2009). Immunosuppressive regimen influences incidence of skin cancer in renal and pancreatic transplant recipients. Transplantation, Vol.88, No.12, (December 2009), pp. 1398-9, ISSN 1534-6080

Loser, K.; Apelt, J.; Voskort, M.; Mohaupt, M.; Balkow, S.; Schwarz, T.; Grabbe, S. \& Beissert, S. (2007). IL-10 controls ultraviolet-induced carcinogenesis in mice. J Immunol, Vol.179, No.1, (July 2007), pp. 365-71, ISSN 0022-1767

Loser, K.; Mehling, A.; Loeser, S.; Apelt, J.; Kuhn, A.; Grabbe, S.; Schwarz, T.; Penninger, J.M. \& Beissert, S. (2006). Epidermal RANKL controls regulatory T-cell numbers via activation of dendritic cells. Nat Med, Vol.12, No.12, (December 2006), pp. 1372-9, ISSN 1078-8956

Maeda, A.; Beissert, S.; Schwarz, T. \& Schwarz, A. (2008). Phenotypic and functional characterization of ultraviolet radiation-induced regulatory $\mathrm{T}$ cells. J Immunol, Vol.180, No.5, (March 2008), pp. 3065-71, ISSN 0022-1767

Mahnke, K.; Qian, Y.; Knop, J. \& Enk, A.H. (2003). Induction of CD4 ${ }^{+} / \mathrm{CD} 25^{+}$regulatory T cells by targeting of antigens to immature dendritic cells. Blood, Vol.101, No.12, (Junuary 2003), pp. 4862-9, ISSN 0006-4971

Majewski, S.; Jantschitsch, C.; Maeda, A.; Schwarz, T. \& Schwarz, A. (2010). IL-23 antagonizes UVR-induced immunosuppression through two mechanisms: reduction of UVR-induced DNA damage and inhibition of UVR-induced regulatory T cells. J Invest Dermatol, Vol.130, No.2, (February 2010), pp. 554-62, ISSN 1523-1747

Markovitsi, D.; Gustavsson, T. \& Banyasz, A. (2010). Absorption of UV radiation by DNA: spatial and temporal features. Mutat Res, Vol.704, No.1-3, (April 2010), pp. 21-8, ISSN 0027-5107

Matsumura, Y.; Moodycliffe, A.M.; Nghiem, D.X.; Ullrich, S.E. \& Ananthaswamy, H.N. (2005). Inverse relationship between increased apoptosis and decreased skin cancer in UV-irradiated CD1d-/- mice. Photochem Photobiol, Vol.81, No.1, (January 2005), pp. 46-51, ISSN 0031-8655

Maurer, M.; Seidel-Guyenot, W.; Metz, M.; Knop, J. \& Steinbrink, K. (2003). Critical role of IL-10 in the induction of low zone tolerance to contact allergens. J Clin Invest, Vol.112, No.3, (August 2003), pp. 432-9, ISSN 0021-9738

Mitchell, D.L.; Jen, J. \& Cleaver, J.E. (1992). Sequence specificity of cyclobutane pyrimidine dimers in DNA treated with solar (ultraviolet B) radiation. Nucleic Acids Res, Vol.20, No.2, (January 1992), pp. 225-9, ISSN 0305-1048

Miyauchi-Hashimoto, H.; Tanaka, K. \& Horio, T. (1996). Enhanced inflammation and immunosuppression by ultraviolet radiation in xeroderma pigmentosum group A (XPA) model mice. J Invest Dermatol, Vol.107, No.3, (September 1996), pp. 343-8, ISSN 0022-202X 
Moloney, F.J.; Comber, H.; O'Lorcain, P.; O'Kelly, P.; Conlon, P.J. \& Murphy, G.M. (2006). A population-based study of skin cancer incidence and prevalence in renal transplant recipients. Br J Dermatol, Vol.154, No.3, (March 2006), pp. 498-504, ISSN 0007-0963

Moodycliffe, A.M.; Bucana, C.D.; Kripke, M.L.; Norval, M. \& Ullrich, S.E. (1996). Differential effects of a monoclonal antibody to cis-urocanic acid on the suppression of delayed and contact hypersensitivity following ultraviolet irradiation. J Immunol, Vol.157, No.7, (October 1996), pp. 2891-9, ISSN 0022-1767

Moodycliffe, A.M.; Nghiem, D.; Clydesdale, G. \& Ullrich, S.E. (2000). Immune suppression and skin cancer development: regulation by NKT cells. Nat Immunol, Vol.1, No.6, (December 2000), pp. 521-5, ISSN 1529-2908

Mouret, S.; Baudouin, C.; Charveron, M.; Favier, A.; Cadet, J. \& Douki, T. (2006). Cyclobutane pyrimidine dimers are predominant DNA lesions in whole human skin exposed to UVA radiation. Proc Natl Acad Sci U S A, Vol.103, No.37, (September 2006), pp. 13765-70, ISSN 0027-8424

Muller, G.; Saloga, J.; Germann, T.; Schuler, G.; Knop, J. \& Enk, A.H. (1995). IL-12 as mediator and adjuvant for the induction of contact sensitivity in vivo. J Immunol, Vol.155, No.10, (November 1995), pp. 4661-8, ISSN 0022-1767

Nghiem, D.X.; Kazimi, N.; Clydesdale, G.; Ananthaswamy, H.N.; Kripke, M.L. \& Ullrich, S.E. (2001). Ultraviolet A radiation suppresses an established immune response: Implications for sunscreen design. J Invest Dermatol, Vol.117, (November 2001), pp. 1193-9, ISSN 0022-1767

Nghiem, D.X.; Kazimi, N.; Mitchell, D.L.; Vink, A.A.; Ananthaswamy, H.N.; Kripke, M.L. \& Ullrich, S.E. (2002). Mechanisms underlying the suppression of established immune responses by ultraviolet radiation. J Invest Dermatol, Vol.119, (September 2002), pp. 600-8, ISSN 0022-202X

Nishigori, C.; Yarosh, D.; O'Connor, A.; Shreedhar, V.K.; Ullrich, S.E.; Cox, P. \& Kripke, M.L. (1998). HindIII liposomes suppress delayed-type hypersensitivity responses in vivo and induce epidermal IL-10 in vitro. J Immunol, Vol.161, No.6, (September 1998), pp. 2684-91, ISSN 0022-1767

Nishigori, C.; Yarosh, D.B.; Ullrich, S.E.; Vink, A.A.; Bucana, C.D.; Roza, L. \& Kripke, M.L. (1996). Evidence that DNA damage triggers interleukin 10 cytokine production in UV-irradiated murine keratinocytes. Proc Natl Acad Sci U S A, Vol.93, No.19, (September 1996), pp. 10354-9, ISSN 0027-8424

Nishikawa, H.; Kato, T.; Hirayama, M.; Orito, Y.; Sato, E.; Harada, N.; Gnjatic, S.; Old, L.J. \& Shiku, H. (2008). Regulatory $\mathrm{T}$ cell-resistant CD8+ $\mathrm{T}$ cells induced by glucocorticoid-induced tumor necrosis factor receptor signaling. Cancer Res, Vol.68, No.14, (Jul 15 2008), pp. 5948-54, ISSN 1538-7445

Nishikawa, H.; Kato, T.; Tanida, K.; Hiasa, A.; Tawara, I.; Ikeda, H.; Ikarashi, Y.; Wakasugi, H.; Kronenberg, M.; Nakayama, T.; Taniguchi, M.; Kuribayashi, K.; Old, L.J. \& Shiku, H. (2003). CD4 ${ }^{+} \mathrm{CD}^{2} 5^{+} \mathrm{T}$ cells responding to serologically defined autoantigens suppress antitumor immune responses. Proc Natl Acad Sci U S A, Vol.100, No.19, (September 2003), pp. 10902-6, ISSN 0027-8424

Nishikawa, H.; Kato, T.; Tawara, I.; Saito, K.; Ikeda, H.; Kuribayashi, K.; Allen, P.M.; Schreiber, R.D.; Sakaguchi, S.; Old, L.J. \& Shiku, H. (2005). Definition of target 
antigens for naturally occurring CD4+ CD25+ regulatory T cells. J Exp Med, Vol.201, No.5, (March 2005), pp. 681-6, ISSN 0022-1007

Nishikawa, H.; Kato, T.; Tawara, I.; Takemitsu, T.; Saito, K.; Wang, L.; Ikarashi, Y.; Wakasugi, H.; Nakayama, T.; Taniguchi, M.; Kuribayashi, K.; Old, L.J. \& Shiku, H. (2005). Accelerated chemically induced tumor development mediated by $\mathrm{CD} 4{ }^{+} \mathrm{CD} 25^{+}$regulatory T cells in wild-type hosts. Proc Natl Acad Sci U S A, Vol.102, No.26, (June 2005), pp. 9253-7, ISSN 0027-8424

Noonan, F.P.; De Fabo, E.C. \& Kripke, M.L. (1981). Suppression of contact hypersensitivity by ultraviolet radiation: an experimental model. Springer Semin Immunopathol, Vol.4, No.3, (1981), pp. 293-304, ISSN 0344-4325

Norval, M.; Gibbs, N.K. \& Gilmour, J. (1995). The role of urocanic acid in UV-induced immunosuppression: recent advances (1992-1994). Photochem Photobiol, Vol.62, No.2, (August 1995), pp. 209-17, ISSN 0031-8655

Perdiz, D.; Grof, P.; Mezzina, M.; Nikaido, O.; Moustacchi, E. \& Sage, E. (2000). Distribution and repair of bipyrimidine photoproducts in solar UV-irradiated mammalian cells. Possible role of Dewar photoproducts in solar mutagenesis. J Biol Chem, Vol.275, No.35, (September 2000), pp. 26732-42, ISSN 0021-9258

Peuhu, E.; Kaunisto, A.; Laihia, J.K.; Leino, L. \& Eriksson, J.E. (2010). Molecular targets for the protodynamic action of cis-urocanic acid in human bladder carcinoma cells. BMC Cancer, Vol.10, (October 2010), pp. 521, ISSN 1471-2407

Ping, X.L.; Ratner, D.; Zhang, H.; Wu, X.L.; Zhang, M.J.; Chen, F.F.; Silvers, D.N.; Peacocke, M. \& Tsou, H.C. (2001). PTCH mutations in squamous cell carcinoma of the skin. J Invest Dermatol, Vol.116, No.4, (April 2001), pp. 614-6, ISSN 0022-202X

Pot, C.; Jin, H.; Awasthi, A.; Liu, S.M.; Lai, C.Y.; Madan, R.; Sharpe, A.H.; Karp, C.L.; Miaw, S.C.; Ho, I.C. \& Kuchroo, V.K. (2009). Cutting edge: IL-27 induces the transcription factor c-Maf, cytokine IL-21, and the costimulatory receptor ICOS that coordinately act together to promote differentiation of IL-10-producing Tr1 cells. J Immunol, Vol.183, No.2, (July 2009), pp. 797-801, ISSN 1550-6606

Pothof, J.; Verkaik, N.S.; Hoeijmakers, J.H. \& van Gent, D.C. (2009). MicroRNA responses and stress granule formation modulate the DNA damage response. Cell Cycle, Vol.8, No.21, (November 2009), pp. 3462-8, ISSN 1551-4005

Rees, J. (1994). Genetic alterations in non-melanoma skin cancer. J Invest Dermatol, Vol.103, No.6, (December 1994), pp. 747-50, ISSN 0022-202X

Rigel, D.S. (2008). Cutaneous ultraviolet exposure and its relationship to the development of skin cancer. J Am Acad Dermatol, Vol.58, No.5 Suppl 2, (May 2008), pp. S129-32, ISSN 1097-6787

Rivas, J.M. \& Ullrich, S.E. (1992). Systemic suppression of DTH by supernatants from UVirradiated keratinocytes: an essential role for keratinocyte-derived IL-10. J Immunol, Vol.149, (December 1992), pp. 3865-71, ISSN 0022-1767

Rivas, J.M. \& Ullrich, S.E. (1994). The role of IL-4, IL-10, and TNF- $\alpha$ in the immune suppression induced by ultraviolet radiation. J Leukoc Biol, Vol.56, (December 1994), pp. 769-75, ISSN 0741-5400

Roberts, L.K.; Lynch, D.H. \& Daynes, R.A. (1982). Evidence for two functionally distinct cross-reactive tumor antigens associated with ultraviolet light and chemically 
induced tumors. Transplantation, Vol.33, No.4, (April 1982), pp. 352-60, ISSN 00411337

Rochette, P.J.; Therrien, J.P.; Drouin, R.; Perdiz, D.; Bastien, N.; Drobetsky, E.A. \& Sage, E. (2003). UVA-induced cyclobutane pyrimidine dimers form predominantly at thymine-thymine dipyrimidines and correlate with the mutation spectrum in rodent cells. Nucleic Acids Res, Vol.31, No.11, (June 2003), pp. 2786-94, ISSN 13624962

Roncarolo, M.G.; Gregori, S.; Battaglia, M.; Bacchetta, R.; Fleischhauer, K. \& Levings, M.K. (2006). Interleukin-10-secreting type 1 regulatory $\mathrm{T}$ cells in rodents and humans. Immunol Rev, Vol.212, (August 2006), pp. 28-50, ISSN 0105-2896

Runger, T.M. (2007). How different wavelengths of the ultraviolet spectrum contribute to skin carcinogenesis: the role of cellular damage responses. J Invest Dermatol, Vol.127, No.9, (Sepember 2007), pp. 2103-5, ISSN 1523-1747

Sakaguchi, S.; Wing, K. \& Miyara, M. (2007). Regulatory T cells - a brief history and perspective. Eur J Immunol, Vol.37 Suppl 1, (November 2007), pp. S116-23, ISSN 0014-2980

Saridaki, Z.; Liloglou, T.; Zafiropoulos, A.; Koumantaki, E.; Zoras, O. \& Spandidos, D.A. (2003). Mutational analysis of CDKN2A genes in patients with squamous cell carcinoma of the skin. Br J Dermatol, Vol.148, No.4, (April 2003), pp. 638-48, ISSN 0007-0963

Schmitt, D.A.; Owen-Schaub, L. \& Ullrich, S.E. (1995). Effect of IL-12 on immune suppression and suppressor cell induction by ultraviolet radiation. J Immunol, Vol.154, No.10, (May 1995), pp. 5114-20, ISSN 0022-1767

Schwarz, A.; Beissert, S.; Grosse-Heithmeyer, K.; Gunzer, M.; Bluestone, J.A.; Grabbe, S. \& Schwarz, T. (2000). Evidence for functional relevance of CTLA-4 in ultravioletradiation-induced tolerance. J Immunol, Vol.165, (August 2000), pp. 1824-31, ISSN 0022-1767

Schwarz, A.; Grabbe, S.; Aragane, Y.; Sandkuhl, K.; Riemann, H.; Luger, T.A.; Kubin, M.; Trinchieri, G. \& Schwarz, T. (1996). Interleukin-12 prevents ultraviolet B-induced local immunosuppression and overcomes UVB-induced tolerance. J Invest Dermatol, Vol.106, No.6, (Jun e1996), pp. 1187-91, ISSN 0022-202X

Schwarz, A.; Maeda, A.; Kernebeck, K.; van Steeg, H.; Beissert, S. \& Schwarz, T. (2005). Prevention of UV radiation-induced immunosuppression by IL-12 is dependent on DNA repair. J Exp Med, Vol.201, No.2, (January 2005), pp. 173-9, ISSN 0022-1007

Schwarz, A.; Maeda, A.; Stander, S.; van Steeg, H. \& Schwarz, T. (2006). IL-18 reduces ultraviolet radiation-induced DNA damage and thereby affects photoimmunosuppression. J Immunol, Vol.176, No.5, (March 2006), pp. 2896-901, ISSN 0022-1767

Schwarz, A.; Maeda, A.; Wild, M.K.; Kernebeck, K.; Gross, N.; Aragane, Y.; Beissert, S.; Vestweber, D. \& Schwarz, T. (2004). Ultraviolet radiation-induced regulatory T cells not only inhibit the induction but can suppress the effector phase of contact hypersensitivity. J Immunol, Vol.172, (January 2004), pp. 1036-43, ISSN 0022-1767

Schwarz, A.; Stander, S.; Berneburg, M.; Bohm, M.; Kulms, D.; van Steeg, H.; GrosseHeitmeyer, K.; Krutmann, J. \& Schwarz, T. (2002). Interleukin-12 suppresses 
ultraviolet radiation-induced apoptosis by inducing DNA repair. Nat Cell Biol, Vol.4, No.1, (January 2002), pp. 26-31, ISSN 1465-7392

Schwarz, T. (2010). The dark and the sunny sides of UVR-induced immunosuppression: photoimmunology revisited. J Invest Dermatol, Vol.130, No.1, (January 2010), pp. 4954, ISSN 1523-1747

Selcuklu, S.D.; Donoghue, M.T. \& Spillane, C. (2009). miR-21 as a key regulator of oncogenic processes. Biochem Soc Trans, Vol.37, No.Pt 4, (August 2009), pp. 918-25, ISSN 14708752

Shankaran, V.; Ikeda, H.; Bruce, A.T.; White, J.M.; Swanson, P.E.; Old, L.J. \& Schreiber, R.D. (2001). IFN $\gamma$ and lymphocytes prevent primary tumour development and shape tumour immunogenicity. Nature, Vol.410, No.6832, (April 2001), pp. 1107-11, ISSN 0028-0836

Shen, J.; Bao, S. \& Reeve, V.E. (1999). Modulation of IL-10, IL-12, and IFN- $\gamma$ in the epidermis of hairless mice by UVA $(320-400 \mathrm{~nm})$ and UVB $(280-320 \mathrm{~nm})$ radiation. J Invest Dermatol, Vol.113, No.6, (December 1999), pp. 1059-64, ISSN 0022-202X

Shreedhar, V.; Giese, T.; Sung, V.W. \& Ullrich, S.E. (1998). A cytokine cascade including prostaglandin E2, IL-4, and IL-10 is responsible for UV-induced systemic immune suppression. J Immunol, Vol.160, (April 1998), pp. 3783-9, ISSN 0022-1767

Smyth, M.J.; Crowe, N.Y. \& Godfrey, D.I. (2001). NK cells and NKT cells collaborate in host protection from methylcholanthrene-induced fibrosarcoma. Int Immunol, Vol.13, No.4, (April 2001), pp. 459-63, ISSN 0953-8178

Soufir, N.; Moles, J.P.; Vilmer, C.; Moch, C.; Verola, O.; Rivet, J.; Tesniere, A.; Dubertret, L. \& Basset-Seguin, N. (1999). P16 UV mutations in human skin epithelial tumors. Oncogene, Vol.18, No.39, (Sepember 1999), pp. 5477-81, ISSN 0950-9232

Sparrow, L.E.; Eldon, M.J.; English, D.R. \& Heenan, P.J. (1998). p16 and p21WAF1 protein expression in melanocytic tumors by immunohistochemistry. Am J Dermatopathol, Vol.20, No.3, (June 1998), pp. 255-61, ISSN 0193-1091

Spellman, C.W. \& Daynes, R.A. (1977). Modification of immunological potential by ultraviolet radiation. II. Generation of suppressor cells in short-term UV-irradiated mice. Transplantation, Vol.24, No.2, (August 1977), pp. 120-6, ISSN 0041-1337

Spellman, C.W. \& Daynes, R.A. (1984). Cross-reactive transplantation antigens between UVirradiated skin and UV-induced tumors. Photodermatol, Vol.1, No.4, (August 1984), pp. 164-9, ISSN 0108-9684

Spellman, C.W.; Woodward, J.G. \& Daynes, R.A. (1977). Modification of immunological potential by ultraviolet radiation. I. Immune status of short-term UV-irradiated mice. Transplantation, Vol.24, No.2, (August 1977), pp. 112-9, ISSN 0041-1337

Spencer, J.M.; Kahn, S.M.; Jiang, W.; DeLeo, V.A. \& Weinstein, I.B. (1995). Activated ras genes occur in human actinic keratoses, premalignant precursors to squamous cell carcinomas. Arch Dermatol, Vol.131, No.7, (July 1995), pp. 796-800, ISSN 0003-987X

Sreevidya, C.S.; Fukunaga, A.; Khaskhely, N.M.; Masaki, T.; Ono, R.; Nishigori, C. \& Ullrich, S.E. (2010). Agents that reverse UV-Induced immune suppression and photocarcinogenesis affect DNA repair. J Invest Dermatol, Vol.130, No.5, (May 2010), pp. 1428-37, ISSN 1523-1747 
Street, S.E.; Cretney, E. \& Smyth, M.J. (2001). Perforin and interferon-gamma activities independently control tumor initiation, growth, and metastasis. Blood, Vol.97, No.1, (January 2001), pp. 192-7, ISSN 0006-4971

Street, S.E.A.; Trapani, J.A.; MacGregor, D. \& Smyth, M.J. (2002). Suppression of lymphoma and epithelial malignancies effected by interferon gamma. J Exp Med, Vol.196, No.1, (July 2002), pp. 129-34, ISSN 0022-1007

Toda, M.; Wang, L.; Ogura, S.; Torii, M.; Kurachi, M.; Kakimi, K.; Nishikawa, H.; Matsushima, K.; Shiku, H.; Kuribayashi, K. \& Kato, T. (2011). UV irradiation of immunized mice induces type 1 regulatory $\mathrm{T}$ cells that suppress tumor antigen specific cytotoxic T lymphocyte responses. Int J Cancer, (201), in press

Toews, G.B.; Bergstresser, P.R. \& Streilein, J.W. (1980). Epidermal Langerhans cell density determines whether contact hypersensitivity or unresponsiveness follows skin painting with DNFB. J Immunol, Vol.124, No.1, (January 1980), pp. 445-53, ISSN 0022-1767

Tremezaygues, L.; Seifert, M.; Tilgen, W. \& Reichrath, J. (2009). 1,25-dihydroxyvitamin D(3) protects human keratinocytes against UV-B-induced damage: In vitro analysis of cell viability/proliferation, DNA-damage and -repair. Dermatoendocrinol, Vol.1, No.4, (July 2009), pp. 239-45, ISSN 1938-198

Trinchieri, G. (2003). Interleukin-12 and the regulation of innate resistance and adaptive immunity. Nat Rev Immunol, Vol.3, No.2, (February 2003), pp. 133-46, ISSN 14741733

Tyrrell, R.M. (1994). The molecular and cellular pathology of solar ultraviolet radiation. Mol Aspects Med, Vol.15, No.1, (January 1994), pp. 1-77, ISSN 0098-2997

Ullrich, S.E. \& Kripke, M.L. (1984). Mechanisms in the suppression of tumor rejection produced in mice by repeated UV irradiation. J Immunol, Vol.133, No.5, (November 1984), pp. 2786-90, ISSN 0022-1767

Ullrich, S.E.; Nghiem, D.X. \& Khaskina, P. (2007). Suppression of an established immune response by UVA--a critical role for mast cells. Photochem Photobiol, Vol.83, No.5, (September 2007), pp. 1095-100, ISSN 0031-8655

Urbach, F. (1991). Potential health effects of climatic change: effects of increased ultraviolet radiation on man. Environ Health Perspect, Vol.96, (December 1991), pp. 175-6, ISSN 0091-6765

Vajdic, C.M.; McDonald, S.P.; McCredie, M.R.E.; van Leeuwen, M.T.; Stewart, J.H.; Law, M.; Chapman, J.R.; Webster, A.C.; Kaldor, J.M. \& Grulich, A.E. (2006). Cancer incidence before and after kidney transplantation. JAMA, Vol.296, No.23, (December 2006), pp. 2823-31, ISSN 1538-3598

van der Schroeff, J.G.; Evers, L.M.; Boot, A.J. \& Bos, J.L. (1990). Ras oncogene mutations in basal cell carcinomas and squamous cell carcinomas of human skin. J Invest Dermatol, Vol.94, No.4, (April 1990), pp. 423-5, ISSN 0022-202X

Vesely, M.D.; Kershaw, M.H.; Schreiber, R.D. \& Smyth, M.J. (2011). Natural innate and adaptive immunity to cancer. Annu Rev Immunol, Vol.29, (April 2011), pp. 235-71, ISSN 1545-3278

Vieira, P.L.; Christensen, J.R.; Minaee, S.; J., O.N.E.; Barrat, F.J.; Boonstra, A.; Barthlott, T.; Stockinger, B.; Wraith, D.C. \& O'Garra, A. (2004). IL-10 secreting regulatory T cells do not express Foxp3 but have comparable regulatory function to naturally 
occurring CD4 ${ }^{+} \mathrm{CD} 25^{+}$regulatory T cells. J Immunol, Vol.172, (May 2004), pp. 598693, ISSN 0022-1767

Wakkach, A.; Cottrez, F. \& Groux, H. (2001). Differentiation of regulatory T cells 1 is induced by CD2 costimulation. J Immunol, Vol.167, (September 2001), pp. 3107-13, ISSN 0022-1767

Wakkach, A.; Founier, N.; Brun, V.; Breittmayer, J.-P.; Cottrez, F. \& Groux, H. (2003). Characterization of dendritic cells that induce tolerance and $\mathrm{T}$ regulatory 1 cell differentiation in vivo. Immunity, Vol.18, (May 2003), pp. 605-17, ISSN 1074-7613

Walterscheid, J.P.; Nghiem, D.X.; Kazimi, N.; Nutt, L.K.; McConkey, D.J.; Norval, M. \& Ullrich, S.E. (2006). Cis-urocanic acid, a sunlight-induced immunosuppressive factor, activates immune suppression via the 5-HT2A receptor. Proc Natl Acad Sci U $S$ A, Vol.103, No.46, (November 2006), pp. 17420-5, ISSN 0027-8424

Waltz, P. \& Chodick, G. (2008). Assessment of ecological regression in the study of colon, breast, ovary, non-Hodgkin's lymphoma, or prostate cancer and residential UV. Eur J Cancer Prev, Vol.17, No.3, (June 2008), pp. 279-86, ISSN 1473-5709

Wang, L.; Saito, K.; Toda, M.; Hori, T.; Torii, M.; Ma, N.; Katayama, N.; Shiku, H.; Kuribayashi, K. \& Kato, T. (2010). UV irradiation after immunization induces type 1 regulatory $\mathrm{T}$ cells that suppress Th2-type immune responses via secretion of IL-10. Immunobiology, Vol.215, (May 2010), pp. 124-32, ISSN 1878-3279

Wang, L.; Toda, M.; Saito, K.; Hori, T.; Horii, T.; Shiku, H.; Kuribayashi, K. \& Kato, T. (2008). Post-immune UV-irradiation induces Tr1-like regulatory $\mathrm{T}$ cells that suppress humoral immune responses. Int Immunol, Vol.20, (January 2008), pp. 57-70, ISSN 1460-2377

Wogan, G.N.; Hecht, S.S.; Felton, J.S.; Conney, A.H. \& Loeb, L.A. (2004). Environmental and chemical carcinogenesis. Semin Cancer Biol, Vol.14, No.6, (December 2004), pp. 47386, ISSN 1044-579X

Wood, R.D.; Mitchell, M. \& Lindahl, T. (2005). Human DNA repair genes, 2005. Mutat Res, Vol.577, No.1-2, (September 2005), pp. 275-83, ISSN 0027-5107

Xu, J.; Yang, Y.; Qiu, G.; Lal, G.; Wu, Z.; Levy, D.E.; Ochando, J.C.; Bromberg, J.S. \& Ding, Y. (2009). c-Maf regulates IL-10 expression during Th17 polarization. J Immunol, Vol.182, No.10, (May 2009), pp. 6226-36, ISSN 1550-6606

Yarosh, D.; Alas, L.G.; Yee, V.; Oberyszyn, A.; Kibitel, J.T.; Mitchell, D.; Rosenstein, R.; Spinowitz, A. \& Citron, M. (1992). Pyrimidine dimer removal enhanced by DNA repair liposomes reduces the incidence of UV skin cancer in mice. Cancer Res, Vol.52, No.15, (August 1992), pp. 4227-31, ISSN 0008-5472

Yarosh, D.; Klein, J.; O'Connor, A.; Hawk, J.; Rafal, E. \& Wolf, P. (2001). Effect of topically applied T4 endonuclease $\mathrm{V}$ in liposomes on skin cancer in xeroderma pigmentosum: a randomised study. Xeroderma Pigmentosum Study Group. Lancet, Vol.357, No.9260, (March 2001), pp. 926-9, ISSN 0140-6736

Zhang, H.; Ping, X.L.; Lee, P.K.; Wu, X.L.; Yao, Y.J.; Zhang, M.J.; Silvers, D.N.; Ratner, D.; Malhotra, R.; Peacocke, M. \& Tsou, H.C. (2001). Role of PTCH and p53 genes in early-onset basal cell carcinoma. Am J Pathol, Vol.158, No.2, (February 2001), pp. 381-5, ISSN 0002-9440

Zhang, X.; Rosenstein, B.S.; Wang, Y.; Lebwohl, M.; Mitchell, D.M. \& Wei, H. (1997). Induction of 8-oxo-7,8-dihydro-2'-deoxyguanosine by ultraviolet radiation in calf 
thymus DNA and HeLa cells. Photochem Photobiol, Vol.65, No.1, (January 1997), pp. 119-24, ISSN 0031-8655

Zhang, Y.; Holford, T.R.; Leaderer, B.; Boyle, P.; Zhu, Y.; Wang, R.; Zou, K.; Zhang, B.; Wise, J.P., Sr.; Qin, Q.; Kilfoy, B.; Han, J. \& Zheng, T. (2007). Ultraviolet radiation exposure and risk of non-Hodgkin's lymphoma. Am J Epidemiol, Vol.165, No.11, (June 2007), pp. 1255-64, ISSN 0002-9262

Ziegler, A.; Jonason, A.S.; Leffell, D.J.; Simon, J.A.; Sharma, H.W.; Kimmelman, J.; Remington, L.; Jacks, T. \& Brash, D.E. (1994). Sunburn and p53 in the onset of skin cancer. Nature, Vol.372, No.6508, (December 1994), pp. 773-6, ISSN 0028-0836

Ziegler, A.; Leffell, D.J.; Kunala, S.; Sharma, H.W.; Gailani, M.; Simon, J.A.; Halperin, A.J.; Baden, H.P.; Shapiro, P.E.; Bale, A.E. \& et al. (1993). Mutation hotspots due to sunlight in the p53 gene of nonmelanoma skin cancers. Proc Natl Acad Sci U S A, Vol.90, No.9, (May 1993), pp. 4216-20, ISSN 0027-8424 


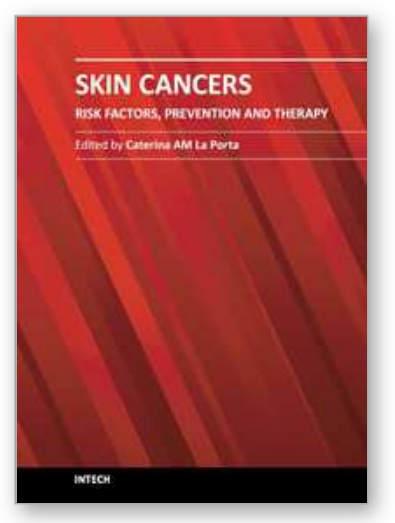

\author{
Skin Cancers - Risk Factors, Prevention and Therapy \\ Edited by Prof. Caterina La Porta
}

ISBN 978-953-307-722-2

Hard cover, 272 pages

Publisher InTech

Published online 14, November, 2011

Published in print edition November, 2011

Skin cancers are the fastest growing type of cancer in the United States and represent the most commonly diagnosed malignancy, surpassing lung, breast, colorectal and prostate cancer. In Europe, the British Isles have been the highest rates of skin cancer in children and adolescents. The overall idea of this book is to provide the reader with up to date information on the possible tools to use for prevention, diagnosis and treatment of skin cancer. Three main issues are discussed: risk factors, new diagnostic tools for prevention and strategies for prevention and treatment of skin cancer using natural compounds or nano-particle drug delivery and photodynamic therapy.

\title{
How to reference
}

In order to correctly reference this scholarly work, feel free to copy and paste the following:

Takuma Kato and Linan Wang (2011). UV-Induced Immune Suppression that Promotes Skin Cancer Development and Progression, Skin Cancers - Risk Factors, Prevention and Therapy, Prof. Caterina La Porta (Ed.), ISBN: 978-953-307-722-2, InTech, Available from: http://www.intechopen.com/books/skin-cancers-riskfactors-prevention-and-therapy/uv-induced-immune-suppression-that-promotes-skin-cancer-developmentand-progression

\section{INTECH}

open science | open minds

\section{InTech Europe}

University Campus STeP Ri

Slavka Krautzeka 83/A

51000 Rijeka, Croatia

Phone: +385 (51) 770447

Fax: +385 (51) 686166

www.intechopen.com

\section{InTech China}

Unit 405, Office Block, Hotel Equatorial Shanghai

No.65, Yan An Road (West), Shanghai, 200040, China

中国上海市延安西路65号上海国际贵都大饭店办公楼405单元

Phone: +86-21-62489820

Fax: $+86-21-62489821$ 
(C) 2011 The Author(s). Licensee IntechOpen. This is an open access article distributed under the terms of the Creative Commons Attribution 3.0 License, which permits unrestricted use, distribution, and reproduction in any medium, provided the original work is properly cited. 